\title{
أثر التدريب على جودة الحياة الوظيفية \\ (دراسة ميدانية على العاملين في البنك الأهلي التجاري)
}

The Impact of Training on Quality of Work Life (A Field Study on Workers in the National Commercial Bank)

\author{
إعداد الباحثة/ سحر محمد أحمد الغامدي \\ ماجستير إدارة الموارد البشرية، كلية الأعمال، جامعة جدة، المملكة العربية السعودية
}

Email: sahar-1991@ outlook.com

\section{ملخص الاراسة - ماسة}

هدفت هذه الدراسة الى دراسة أثر التدريب على جودة الحياة الوظيفية المتمثلة في (الترقي الوظيفي، وظروف العمل الصحية) على العاملين في البنك الأهلي التجاري السعودي في مدينة جدة وهو أول بنك سعودي وطني بالمملكة العربية السعودية وبتأسيسه تمت و لادة الكيان الاقتصادي الر ائد في المملكة. حيث تتمثل مشكلة الدر اسة في التعرف على أثر واقع عملية التدريب المستخدمة في قطاع البنوك السعودية، والى أب مدى يتم تنفيذ هذه العملية وفق الأسس و القو اعد العلمية، حيث يعتبر عدم توفر المورد البشري المؤهل و الكفء من أبرز معوقات الأداء التي تحد من فاعلية وكفاءة المنظمات. يتألف مجتمع الدر اسة من الموظفين العاملين في البنك الأهلي ومن اجل تحقيق أهداف البحث صمدت الباحثة استبيان مؤلف من 16 سؤال من اجل جمع البيانات الأولية من عينات الدر اسة، و التي بلغت (170) استبيان على عينة عشو ائية من العاملين بمختلف مستوياتهم الوظيفية، تم جمع البيانات وتحليلها باستخدام المنهج الوصفي SPSS واختبار الارتباط لتحقيق أهداف الدر اسة.

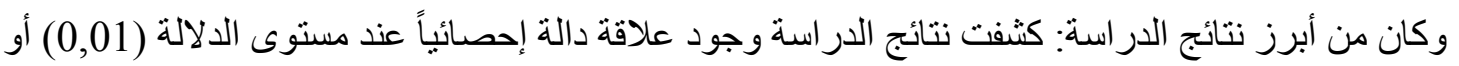
أقل منه، بين مستوى التدريب وتحقيق ظروف العمل الصحية في البنك الأهلي التجاري، ويتبين من قيمة معامل الارتباط (0,784) بأن العلاقة موجبة (طردية) بين المتغيرين، أوضحت نتائج الدراسة وجود علاقة دالة إحصائياً عند مستوى الدلالة (0,01) أو أقل منه، بين مستوى التدريب و الترقي الوظيفي في البنك الأهلي التجاري، ويتبين من قيمة معامل الارتباط (0,805) بأن العلاقة موجبة (طردية) بين المتغيرين. الكلمات المفتاحية. التدريب، جودة الحياة الوظيفية، البنك الأهلي التجاري. 


\section{The Impact of Training on Quality of Work Life (A Field Study on Workers in} the National Commercial Bank)

\section{Abstract}

This study aimed to study the impact of training on the quality of functional life represented in (job promotion, and healthy working conditions) on workers in the Saudi National Commercial Bank in Jeddah, which is the first Saudi national bank in the Kingdom of Saudi Arabia, and with its establishment, the leading economic entity in the Kingdom was born. Where the problem of the study is to identify the impact of the reality of the training process used in the Saudi banking sector, and to what extent this process is implemented in accordance with scientific foundations and rules, where the lack of qualified and efficient human resource is one of the most prominent performance obstacles that limit the effectiveness and efficiency of organizations. The study population consists of employees working in the National Bank. In order to achieve the objectives of the research, the researcher designed a questionnaire consisting of 16 questions in order to collect the primary data from the study samples, which amounted to (170) questionnaires on a random sample of employees of different job levels. The data were collected and analyzed using The descriptive method SPSS and correlation test to achieve the objectives of the study. Among the most prominent results of the study: The results of the study revealed the existence of a statistically significant relationship at the significance level (0.01) or less, between the level of training and achieving healthy working conditions in the National Commercial Bank, and it is clear from the value of the correlation coefficient (0.784) that the relationship is positive (directive). ) Between the two variables, the results of the study showed that there is a statistically significant relationship at the significance level (0.01) or less, between the level of training and job promotion in the National Commercial Bank.

Keywords: training, quality of work-life, the national commercial bank. 


\section{الإهداء}

إلى الذي و هبني كل ما يملك حتى أحقق له آماله، إلى مدرستي الأولى في الحياة، الى الرجل العصامي، أبي

$$
\text { الغالي على قلبي أطال الله في عمره. }
$$

الى التي رعتني حق الرعاية وكانت سندي في الثدائد، ودعو اها لي بالتوفيق تتبعتني خطوة خطوة في عملي، أمي أعز ملاك على القلب و العين جز اها الله عني خير الجزاء في الدارين.

$$
\text { الى طفلي وقرة عيني حسن، مصدر قوتي و إصر اري دائماً. }
$$

الى إخوتي و أخو اني الذين ساندوني منذ بداية رحلتي الدراسية .. نصائحكم، كلماتكم، دعو اتكم .

إليكم أهدي هذا العمل المتو اضع فلم أكن لأصل لما أنا عليه اليوم لو لا فضلكم علي من بعد فضل الله سبحانه.

$$
\text { و الى كل من يتكبد عناء قر اءته .. }
$$

سو اء لتقييمه أو لنقده أو لزيادة علمه أو لإشباع فضوله ..

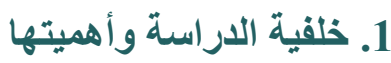

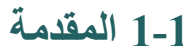

تو اجه منظمات الأعمال السعودية اليوم العديد من التحديات والتغييرات السريعة فمما لا شك فيه أن الاستثمار في تدريب العنصر البشري يحتل مكانة متميزة بين أوجه الاستثمار المختلفة نظر الأهمية الموارد البشرية في تحقيق التتمية والتقدم. و لأن أداء أي جهة أو مؤسسة وتحسن نتائجها وازدهار ها برتبط بأداء موظفيها اتجهت الإدار ات الى الاستثمار في العامليين لديها فعملية تدريب وتطوير الموظفين أصبحت من الركائز الأساسية لتحقيق التميز في قطاع البنوك للارتقاء بمستوى العاملين على اختلاف مستوياتهم للقيام بالأعمال و المهام الموكلة إليهم بكفاءة وفاعلية. وبما أن القطاع المصرفي وخاصة البنوك التجارية دنها لها دور محوري في اقتصاد الدولة فان ذللك يتطلب تتمية وتطوير رأس المال البشري الذي يقوم على أدائها، وفي ضو ذذللك تأتي هذه الدراسة للتعرف على مدى أثر عملية التدريب في المصارف التجارية السعودية وأثره على جودة حياة العاملين في البنك. إن الأساس من عملية التدريب هو إيصال معلومات وتكوين مهار ات معينة لمجموعة من المتدربين بواسطة وسيلة من وسائل الاتصال و أساليب التدريب وذلك بقصد التأثثر على سلوكهم ورفع قدر اتهم الوظيفية، كما أن التدريب يستهدف الفرد لإكسابه المهارة و المعرفة والسلوك المرتبط مباشرة بدوره الوظيفي مما يرفع مستوى إنتاجيته في العمل. لذلك أصبح التدريب عملية مهمة لاى الكثير من المنظمات في كافة القطاعات وذلك نتيجة لتغير معايير الأداء والتي لم تعد قاصرة على مجرد تقديم الخدمة أو المنتج بل تعدته بالحرص على توفير الجودة التي تلبي

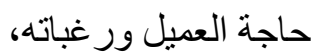


ولذللك أصبح للتنريب أهية كبيرة ومحور اهتمام الكثير من الباحثين والمختصين في مجال الإدارة الحديثة. و وتتناول هذه الدر اسة توضيحاً للمفاهيم المتعلقة بعملية التدريب حيث يوضح مفهوم التدريب و التطور التاريخي و أسباب الاحتياج التدريبي و أنواع التدريب و البر امج التدريبية في البنك و أهمية التدريب و أهدافه وأساليبه كما تتناول مر احل العملية التدريبية. ولأن سمة المنظمات في عصرنا الحالي أنها تمر بالكثير من التغير ات المستمرة في شتى المجالات السياسية والاقتصادية والاجتماعية والتكنولوجية و الثقافية، و انطلاقا من كون المورد البشري هو جو هر موارد المنظمات، ومصدر ا مهما لتحقيق المزايا التنافية لها، ولأن بنجاحه ضمان نجاح المنظمة وتحقيق أهدافها بنسبة كبيرة، كان لابد أن ينعم هؤلاء الموظفين بجودة عالية وكريمة نشعر هم بالرضا نحو المنظمة، للحياة الوظيفية التي تقدمها لهم منظماتهم التي يعملون بها ومدركين لأهمية و إمكانيه وثقة ما يقدمون، ولديهم و لاء حقيقي للمنظمة. لذلك تسعى رؤية المملكة العربية السعودية 2030 إلى خطو خطوات طموحة لرفع مستوى أداء الأفر اد العاملين في جميع القطاعات، عن طريق إكسابهم المهار ات النوعية والأدائية التطويرية في ميادين أعمالهم وزيادة قدر اتهم على التفكير الابتكاري بما يمكنهم من التكيف مع وظائفهم من ناحية ومواجهة مشكلاتهم والتغلب عليها من ناحية أخرى وتتمية الاتجاهات الصحيحة للفرد نحو تقديره لقيمة عمله وأهميته وتعزيز الحس المهني للإخلاص في أداء المهام الموكلة لهم بجودة عالية، ومما لا شك فيه أن كل ما سبق ذكره يعود بفو ائد عالية على المنظمة كزيادة إنتاجيتها وجودتها وزيادة مستويات الالتز ام التنظيمي للعاملين به.

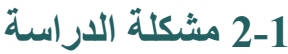

تتمثل مشكلة الدراسة في التعرف على أثر واقع عملية التدريب المستخدمة في قطاع البنوك السعودية، و إلى أي مدى يتم تتفيذ هذه العملية وفق الأسس والقواعد العلمية. حيث يعثبر عدم توفر المورد البشري المؤهل و الكفء من أبرز معوقات الأداء التي تحد من فاعلية وكفاءة المنظمات، فالبنوك التجارية كغير ها من المنظمات التي نواجه تحدي كبير في ظل التطورات المتسارعة في عالم الأعمال الذي أدى بدوره الى ازدياد حدة المنافسة المحلية والدولية وهذا بدوره يسهم في وضع البنوك تحت ضغط مستمر نحو تطوير قدرات مو اردها البشرية لكي تتوفر لديها المهارات و القدرات وتحقيق جودة الحياة الوظيفية لدى جميع العاملين في البنك. تسعى منظمات الأعمال اليوم الى تحسين مستوى جودة حياة العمل من خلال مجموعة من الاستر اتيجيات الخاصة بهاو ومن اهم هذه الاستر اتيجيات هيا استر اتيجية التدريب حيث تساهم في تزويد وصقل احتياجات العاملين و إثباع حاجاتهم وتوقعاتهم حيث أصبحت لدى الإدارة العلياتوجه بإن المؤشر ات المالية وحدها لم تعد كافية للنجاح فأصبح التركيز و الاهتمام بالمورد البشري بشكل كبير ضرورة لتنمية أنو اع معينة من الجدار ات لديهم لما في ذلك من اثر على الأداء العام لمخرجات البنك ويتطلب ذلك الاهتمام بإستر اتيجية التدريب للرفع من مهار ات العاملين بشكل ينسجم مع التطلعات المستقبلية للبنك. 
تهدف هذه الدر اسة إلى در اسة أثر التدريب على جودة الحياة الوظيفية للعاملين لاى قطاع المصارف التجارية السعودية ويندرج تحت هذا الهدف الرئيسي الأهداف الفرعية التالية.

$$
\text { 2-3-1 } 1 \text { ا التعرف على على البر امج التدريبية التي يقدمها قطاع البنوك. }
$$$$
\text { 3-3-1 قياس أثر التدريب على جودة الحياة الوظيفية في قطاع البنوك. }
$$

4-3-1 إغناء المكتبة المحلية والعربية بالمعلومات اللازمة عن أثر التدريب و أهميته في تحسين جودة

$$
\text { الحياة الوظيفية بشكل عام. }
$$

3-1 أسئلة البحث

تتمثل أسئلة البحث فيما يلي.

1-4-1-1 ماهو ا أثر التدريب على جودة حياة العاملين في قطاع البنوك؟ هاجي

2-4-1 هل يوجد اختلاف ذو دلالة إحصائية لأثر التدريب في البنوك تبعا للمتغير (جودة الحياة الوظيفية)؟

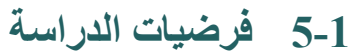

لكي تتمكن الباحثة من الإجابة عن أسئلة الدر اسة وتحقيق أهدافها، فقد تم تطوير عدد من الفرضيات و هي كالتالي.

$$
\text { 1-5-1 توجد علاقة ذات دلاله إحصائية بين التدريب وتحقيق ظروف العمل الصحية. }
$$$$
\text { 2-5-1 نوجد علاقة ذات دلالة إحصائية بين التدريب و الترقي الوظيفي. }
$$

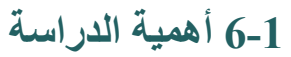

1-6-1 الأهمية العملية (الجاتب الميدانى). تستمد الدارسة أهميتها من خلال أهمية الدور الذي يلعبه التدريب

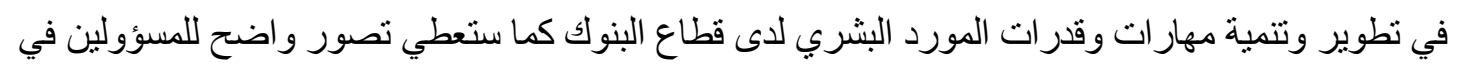
قطاع البنوك عن أثر التدريب على جودة الحياة الوظيفية لدى العاملين في البنلك، و التوصل إلى بعض المقترحات

$$
\text { و التوصيات التي يمكن الاستفادة منها في قطاع المصارف بردكل عام. }
$$

2-6-1 الأهمية العلمية (الجاتب الأكاديمى). يساعد هذا البحث إدارة الموارد البشرية في إدراك العلاقة بين

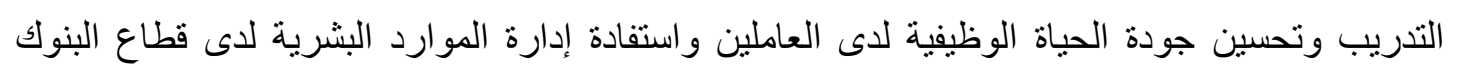

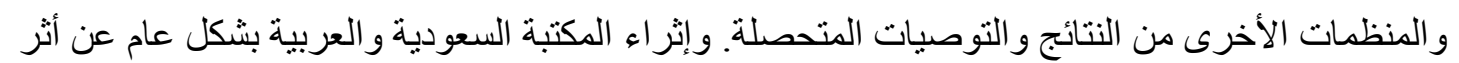
التدريب على جودة الحياة الوظيفية حيث حسب حد علم الباحثة لم تطرق در اسة سابقة لدر اسة المتغير ( جودة الحياة الوظيفية ) في أحد اهم القطاعات في الاقتصاد السعودي إلا و هو قطاع المصارف التجارية، 
هذا وتؤمل الباحثة من هذه الدر اسة تسليط الضوء على و اقع التدريب في البنوك ومساعدة المصارف التجارية السعودية على التعرف على الدور الاستراتيجي في ممارسة التدريب الذي قد يسهم في رفع مستوى جودة حياة العمل بالتالي الرفع من مستوى الخدمات التي تقدمها المصارف لعملائها.

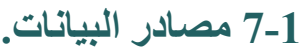

1-7-1 البيانات الأولية. تم تطوير استبانة وتوزيعها على العاملين لجمع البيانات اللازمة لهذه الدر اسة حيث تم توزيع ( ) استبانة، وقد نم التوزيع على مدر اء الوحدات الإدارية والموظفين في فروع البنك الأهلي

$$
\text { التجاري بمدينة جدة. }
$$

2-7-1 البيانات الثانوية.ـوتتمثل هذه البيانات في الكتب والدوريات ذات العلاقة بالموضوع و المقالات المختلفة المتوفرة في شبكة المعلومات (الإنترنت)، كما وتم الاستعانة بالمنشور ات المختلفة.

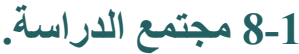

يتكون مجتمع الدر اسة من عدد من موظفي البنك الأهلي التجاري بمدينة جدة.

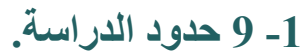

1-9-1 حدود بشرية. اقتصرت الدر اسة على الموظفين لدى البنك الأهلي التجاري بمدينة جدة.

2-9-1 حدود جغر افية. تمت اختيار فروع البنك الأهلي التجاري بمدينة جدة في منطقة مكة المكرمة لتطبيق

الدراسة لأنها مكان تو اجد الباحثة مما يسهل عليها عملية جمع البيانات.

$$
\text { 3-9-1 حدود زمنية. تمت الدر اسة في الفصل الدراسي الثاني من عام } 2020 \text { م. }
$$

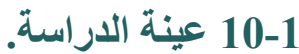

يتألف مجتمع الدراسة من جميع الموظفين المتاحين وقت الدراسة وعددهم (170) موظف، وتثير العينة العشوائية البسيطة إلى مجموعة محدودة يتم اختيارها من المجتمع الإحصائي، حيث يكون لها نفس فرصة الاختبار كعينة من ذللك المجتمع؛ بمعنى أن جميع أفر اد المجتمع لهم فرصة في أن يتم اختيار هم

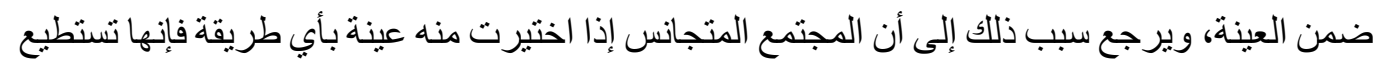
أن تمثله و أن تظهر فيها جميع خصائصه ومميز اته. 
ستقوم الباحثة بتحديد مجال الدراسة والعينة وتوضيح المنهج المتبع وباقي أنواع الأدوات المستخدمة، حيث أن البحث الميداني سينصب على تحليل الواقع الذي يدور فيه البحث خاصة وأن البنك الأهلي

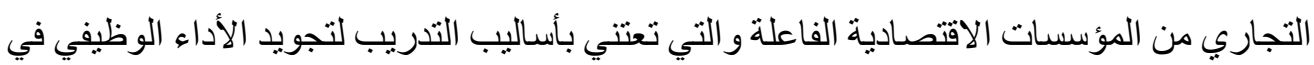

البنك.

\section{2-1 الأسساليب الإحصائية}

لتفعيل الخصائص المميزة لمتغيري الدر اسة سيتم استخدام أسلوب الإحصاء الوصفي في المعالجة الإحصائية وتحليل البيانات التي يتم جمعها و إجر اء الاختبار ات اللازمة باستخدام برنامج الحزمة الإحصائية

للعلوم الاجتماعية (SPSS) واختبار Kolmogorov-Smirnova) و اختبار (Shapiro-Wilk) للوصول للاعتدالية في توزيع البيانات ومعرفة مطابقتها للتوزيع الطبيعي.

\section{2 الإطار النظري والدراسات السابقة}

يتم في هذا الفصل مناقثة الإطار النظري للبحث لمتغيري الدراسة، الأول فيما بتعلق بالمتغير المستقل (التدريب)، و الثاني يتعلق بالمتغير التابع (جودة الحياة الوظيفية)إلى جانب تناول مجمو عة من الدر اسات السابقة التي تتاولت موضوع البحث أو جانباً منه، وقامت الباحثة بالتعليق و التعقيب على تللك الدر اسات ومناقتشة نقاط الاتفاق بين تللك الدراسات و الدراسة الحالية.

تمهيد. Preface تهنم المنظمات بالتدريب لأن ما ينفق فيه يمثل استثمار أ في الموارد البشرية يكون له عائد يظهر في شكل زيادة الإنتاجية الكلية. أما على مستوى الفرد فتظهر أهمية التدريب في زيادة المعارف والمهار ات الأمر الذي قد يؤدي إلى رفع دافعية وقدرة الفرد على العمل. كما يسعى التدريب إلى زيادة مهار ات الأفر اد لأداء عمل محدد. ومجموعة الأنشطة التي تسعى إلى هذا الغرض تمثل في مجموعها أنتطة التدريب، وهو أمر سنتعرض له بالتفصيل في سياق الدراسة كما يمكن اعتبار التدريب على أنه "تأقلم

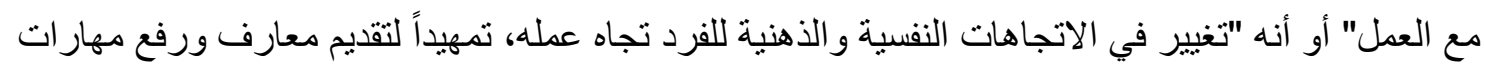
الفرد في أداء العمل. (ماهر،2005). التدريب لغة كلمة مشتقة من كلمة درب و الدرب هوا الطريق فان ذلك يعني وضع الأفراد و الجماعات على الطريق السليم كي يسيروا فيه ويتعودوا عليه، التذريب (بالإنجليزيّة:

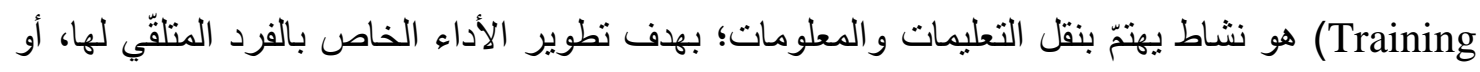

$$
\text { مساعدته على الوصول إلى مرحلة معينة من المهار ات و المعارف. }
$$


Training Concept. 1-1-2 عفرف الباحثون مفهوم التدريب بأكثر من طريقة، لكننا هنانركز على أن التدريب هو الوسيلة التي يمكن بو اسطتها نزويد العاملين بالمهار ات والمعرفة الفنية في مجال معين وأن يؤدي ذللك إلى زيادة فاعلية المتدرب وكفاءته، وعن طريق هذا التدريب يتسنى لمدر اء الإدارات في المؤسسات استخدام القوى العاملة لايهم واستثمار قدر اها أفضل استثمار.

1-1-1-2 يعرف " فيليبو FLIPPO " التدريب في كتابه " مبادئ إدارة الموارد البشرية " بأنها: هو العملية التي من خلالها يتم تزويد العاملين بالمعرفة أو المهارة لأداء وتنفيذ عمل معين، وأن التدريب عمل أو نشاط من أنشطة الموارد البشرية والذي يعمل على تقرير حاجة أداء الأفراد العاملين في مختلف المستويات التنظيمية للتطوير و التأهيل في ضوء نقاط الضعف و القوة الموجودة في أدائهم وسلوكهم خلال العمل.

2-1-1-2 ويعرف بعض الكتاب التدريب بأنه الجهود الإدارية أو التنظيمية التي تهدف على تحسين قدرة الإنسان على أداء عمل معين، أو القيام بدور محدد في المؤسسة التي يعمل فيها، ويعر فه آخرون على أنه إجر اء منظم من شأنه أن يزيد من معلومات ومهار ات الإنسان لتحقيق هدف محدد.

3-1-1-2 يقصد بالتدريب البر امج الرسمية التي تستخدمها المنظمة والمؤسسات لمساعدة القوى العاملة داخل المنظمة على كسب الفاعلية والكفاءة في أعمالهم الحالية والمستقبلية، عن طريق تنمية العادات الفكرية و العملية المناسبة و المهار ات و المعارف و الاتجاهات بما يناسب تحقيق أهداف المنظمة.

4-1-2 2-1 النشاطات المصممة لتقدم للمتدرب المعرفة و المهارة التي يحتاجها لوظيفته الحاليـة.

ومن هنا يمكن القول بأن معظم الباحثين و المفكرين الذين ساهمو ا في تعريف التدريب اشتركو ا أيضا في إيصال فكرة محتو اها أن التدريب يزود الأفر اد بمهار ات معينة تؤدي في النهاية إلى زيادة وتحسين معدلات الأداء لديهر.

2-1-1-2 ترى الباحثة أن التدريب هو عملية منتظمة تهدف إلى تزويد العامل بالمهار ات وبالمعرفة التخصصية، و إحداث تغيير في السلوك لأداء عمله الحالي أو المستقبلي بما بساعد على تحقيق غايات المنظمة، وبضرورة و أهمية ربط التعلم بالتدريب حيث يعتبر التعلم وسيلة للتدريب و لا يمكن من دونه أن تتم عملية التدريب، حيث أن التعلم يهنم بتزويد الأفر اد بالمعرفة العلمية وإيصالهم إلى التفكير السليم أما التدريب فيهتم بنقل المعرفة إلى تطبيق فعلي حيث أن التدريب هو ثمرة التعلم.

2-1-2 التطور التاريخي لعملية التدريب. ظاهرة التدريب موجودة عبر التاريخ فهي ثمرة عمل طويل مستمر خلال الأجيال ويشهد على قدم هذه الظاهرة ما وصل إلينا من معلومات عن الحضار ات القديمة عن طريق الآثار القديمة والحفريات التي كثفت عن حضار ات قديمة وطرق معيشتها ومر اكز التعليم والتدريب فيها، 
تتسم المراحل التي مر بها التدريب تاريخياً بثلاث مراحل أساسية والتي يلخصها كل من (عساف، 2000)

$$
\text { و(ياغي، } 2003 \text { ) فيما يلي. }
$$

1-2-1-2 المرحلة الأولى. ما قبل ظهور الأديان السماوية أبي مرحلة الحضار ات السابقة وتميزت هذه المرحلة بمناهج التفكير الأسطوري و الميتافيزيقي حيث أن أساليب جميع الجوانب الحياتية وأساليب ومهارات التعامل معها يغلب عليها الأساليب الأولية نظر اً لبدائية أساليب التفكير وبدائية وسائل الإنتاج.وبالرغم من ذلك تمكن الإنسان أن ييني خلال هذه المرحلة حضار ات تميزت بالاكتثافات وبناء المعارف و المهار ات و التي من خلالها أمكن للإنسان أن ينتقل إلى المر احل اللاحقة لها كحضار ات ما بين النهرين وو ادي النيل و الصينية و الهندية القديمة

2-2-1-2 المرحلة الثانية. وهي المرحلة التي ظهرت فيها الأديان السماوية ذات الرسالات السماوية كاليهودية و المسيحية والإسلامية وتميزت هذه المرحلة بتقديمها للبشرية نظم تربوية ومعرفية و عقائدية مقننة وتمثل هذه الأديان على المستوى التربوي بالدرجة الأساسية والمستوى المعرفي فيما يتعلق بالجو انب غير المادية الأخرى. و أهم ما واجه هذه المرحلة من تحديات هي التفوق التربوي الذي جسدته منظومة القيم العقائدية التي جاءت بها هذه الرسالات وبالمقابل ذلك الضعف على المستوى التعليمي والذي لم يمكن الإنسان من استيعاب جوهر هذه

ومما يهمنا في هذا الجانب الضعف الأشد على المستوى التدريبي وذلك في انصر اف أصحاب العقائد إلى التشبث و التركيز على الجوانب القيمية والجمود معها وبذلك تخلف العمل التطبيقي واقتصرت مستلزمات الحصول على المهار ات و المعارف التطبيقية مما أدى إلى أن أصحاب هذه العقائد ظلوا يدورون في نفس الدائرة وفي تلك الفلسفة حيث أن التخلف أصبح نتيجة عدم العمل على تطبيق العقيدة وهجر ها والتشبث بالمظلات الوضعية.

3-2-1-2 المرحلة الثالثة. وهي مرحلة ما بعد الثورة الصناعبة التي ترتب عليها تطورات شملت كل وسائل العمل و الإنتاج في تسار عها المتلاحق بصورة مذهلة مما أدى إلى قفزات تطويرية واسعة على مستوى العمليات التعليمية والتدريبية مما أدى إلى بدء تحدي كبير أمام الأفراد و الجماعات يفرض ضرورة الانخر اط لتنمية المعارف و المهار ات اللازمة لتأهيلهم للتكيف مع احتياجات سوق العمل الجديدة.

4-2-1-2 أهمية التدريب. يعمل التدريب على تتمية وتطوير وتوسيع آفاق العاملين، و التفكير المنظم والقدرة على حل المشكلات و التعامل معها والتأقلم مع ديناميكية بيئة العمل المتغيرة. فمن الواجبات الملحة للإدار ات المواكبة للتغير هي تنمية وتدريب العاملين لصقل وتطوير مهار اتهم لإنجاز العمل، ولعل البرامج التدريبية هي العمود الفقري في هيكلة مهام إدارة الموارد البشرية ومن هنا اكتسبت البرامج التدريبية أهمية خاصة وبدأت العناية بها، ويرى (عباس، 2016)، بأن أهمية التدريب تتركز في ثناثة نقاط رئيسية وهي. 
5-2-1-2 زيادة الأرباح و الأداء التنظيمي من خلال الوضوح في الأهداف وتعريف العاملين بما هو مطلوب

منهم وتطوير مهار اتهم وربط أهداف العاملين بأهداف المنظمة مما بساهم في تحقيقها.

6-2-1-2 يساهم في خلق اتجاهات إيجابية داخل المنظمة وخارجية كتحسين سمعتها السوقية مما يساعد في

انفتاحها على المجتمع الخارجي ؛بهدف تطوير بر امجها و إمكانياتها لتنفيذ رؤيتها وصياغة أهدافها.

7-2-1-2 بناء قاعدة فعالة للاتصالات الداخلية، وتطوير أساليب القيادة وترشيد القرارات الإدارية.

(أ) كما أن التدريب كمدخل لاستمر ارية التربية والتطوير من خلال تعديل وتغيير القيم والاتجاهات

التي تحتاج الى تغيير وكذللك تعزيز القيم والاتجاهات التي تكون مشابهة لمنظومة القيم السائدة في

المنظمة.

(ب) كما أن التدريب يسهم بصورة فاعلة في تطوير العلاقات البشرية داخل بيئة العمل، وهذه العلاقات تكون أقوى وأكثر فاعلية عندما تتو افر لاى أفر اد المنظمة تلك المهار ات و الجدارات المطلوبة لأداء العمل، كما إن أهمية التدريب لا تقتصر على تطوير قدرات العاملين إنما تمند تلك الأهمية لتشمل تحسين وتطوير سلوكيات العاملين في العمل وتعاملهم مع المنظمة ومع الزملاء و الرؤساء و المرؤوسين و عملاء المنظمة، بمعنى أن التدريب هنا يفيد في نرشيد الأنماط والعادات السلوكية وتطوير القيم و الاتجاهات النفيسة للعاملين وتكفل لهم المحافظة على تو ازنهم النفسي ومن هنا نلاحظ أن فو ائد التدريب

و أهميته تمند لكي تشمل المؤسسة والموظف أو العامل المتدرب ومجموعة العمل. (ج) فالمنظمة نستفيد من التدريب باعتبار أن التدريب يهدف في النهاية إلى تحسين وتطوير قدر ات العاملين وبالنالي تحسين أدائهم للعمل ومن ثم تحسين وتطوير وزيادة إنتاجية المؤسسة و الموظف أو العامل المتدرب يستفيد من التدريب باكتسابه لمهار ات جديدة تزيد من قدرته على أداء عمله الحالي و هو الأمر الذي يكسبه ميزات مادية ومعنوية فضلا عن زيادة قدرته على أداء أعمال مستقبلية و إتاحة الفرص أمامه للترقي لمناصب ووظائف أعلى في مستقبل حياته الوظيفية.

3-1-2 أهداف التدريب. تعد أهداف التدريب هي الغايات التي يسعى لتحقيقها، وهي عبارة عن نتائج يتم تحديدها و إقرار اها قبل البدء في عملية التدريب، يرى آرم سترونج أن التدريب يهدف الى زيادة مستوى الإدر الك والفهم للعاملين من خلال تطوير المهارات والاتجاهات في جميع الجوانب التي تحتاجها المنظمة، إن نجاح عملية التدريب يتوقف على مجمو عة من الأهداف (Cornelins, 1999) ومن أهم هذه الأهداف ما يلي.

1-3-1-2 يساهم التدريب في تعظيم معرفة ومهارة العاملين وهو ا ما يؤدي الى توفير الرقابة الذاتية.

2-3-1-2 نأهيل قادة الصف الثاني يمكن الاعتماد عليه في تفويض السلطة.

3-3-1-2 يساهم في انخفاض حو ادث و إصابات العمل، نظر اً لأن معظم هذه الإصابات ترجع إلى عدم معرفة 
العامل بأسلوب التشغيل السليم للآلات و المعدات، أو لعدم تفهمه لظروف العمل.

4-3-1-2 يساهم التدريب في زيادة در اية الفرد بالمشكلات التي يمر بهاو الحل الصحيح عند مواجهتها.

5-3-1-2 المو اعمة بين مو اصفات منصب العمل ومو اصفات.

4-1-2 أسباب الاحتباج التدريبي. هناك العديد من الأسباب للاحتياجات التدريبية منها (ماهر ،2005):

1-4-1-2 الترقية. لإلغاء الفجوة بين قدر ات الفرد الحالية و القدر ات المطلوبة في الوظيفة الجديدة.

2-4-1-2 تقييم الأداء. لمعرفة الفرق بين الأداء الفعلي والأداء المتوقع.

3-4-1-2 بر امج تخطيط المسار الوظيفي. ويتم فيه تحديد الوظائف المحتملة في المستقبل الوظيفي للفرد وتأهيله بتتمية قدر اته ومهار اته لشغل هذه الوظائف.

4-4-1-2 حو ادث العمل. عند قصور المعلومات الخاصة بالأمن و الوقاية وكيفية استخدام الأجهزة، فيجب

$$
\text { تدريبهم لتجنب هذه الأخطاء. }
$$

5-4-1-2 الجودة. تدريب الأفر اد بساعد في ارتفاع مستوى جودة العمل.

6-4-1-2 الثكاوى. إذا كانت الثكوى بسبب نقص المعرفة لاى الأفر اد العاملين، وجب تدريبهم.

7-4-1-2 التمكين. عند إسناد مهام خاصة لاحد الأفر اد في حين أن قدر اته الحالية لا ترتقي لمتطلبات هذه

$$
\text { المهمة وجب تدريبه. }
$$

8-4-1-2 إدخال تكنولوجيا جديدة. يسهم التدريب في التقليل من أخطاء العمل التي قد نواجه العاملين عند

إدخال بر امج تكنولوجية جديدة مما يوجب تدريبهم على استخدامها.

$$
\text { 5-1-2 أبعاد التدريب. يرى (ابن عيثي، 2012) أن لمفهوم التدريب ثلاثة أبعاد هي: }
$$

2-1-1-1-1 بعد نظري. و الهدف منه تزويد المتدربين بالمعرفة والخبرة و المعلومات اللازمة.

2-5-1-2 بعد سلوكي. يهدف الى تطوير اتجاهات المتدربين و إكسابهم أنماط إدارية وسلوكية فعالة.

3-5-1-2 بعد عملي. يهدف هذا البعد الى تزويد المتدربين بطرق جديدة لأداء أعمالهم بطريقة أكثر فاعلية. 
6-1-2 أنواع التدريب. باعتبار أن التدريب وسيلة لتحقيق أهداف المنظمة من خلال تنمـية الأفر اد وتحسين مستويات أدائهم، فإنه يختلف باختلاف الهدف مـنه وطبيعة العمل والمستوى الوظيفي. ويختلف من منظمة الى أخرى وحسب مقدرتها المالية و إمكانياتها و عدد الأفر اد الذين يعملون بها. وبناء على ذلك يمكن القول بأن هناك تقسيمات عديدة لأنو اع التدريب، فهناك من يصنفها حسب الهدف و منها من يصنفها حسب المستوى الوظيفي أو نوع الوظيفة وآخرون يصنفونها حسب المكان ومرحلة التوظيف. سوف ينم ذكر الأنواع الثائعة منها: 1-6-1-2 بغرض توجيه الموظف الجديد. لتهيئة العاملين الجدد ولمعرفة الحقوق و الو اجبات و الأمن و السلامة وكل ما يدور ببيئة العمل الداخلية والخارجية.

2-6-1-2 التدريب أثناء العمل. تلجأ المنظمات أحياناً في تقديم التدريب في موقع العمل حتى تضدن كفاءة التدريب وغالبا ما يتم ذللك بو اسطة المشرفين المبانشرون للعمل فيها،

$$
\text { ويتم تقديم المعلومات و التنريب على مستوى فردى للمتدربين. }
$$

3-6-1-2 التدريب للترقية. ينم توفير هذا التدريب للموظفين الحاليين للثركة لإعدادهم لأداء وظائف على إلى

$$
\text { مستوى أعلى. لإكسابهم المهار ات و الخبر ات الجديدة. }
$$

4-6-1-2 التدريب أونلاين. لقد فضلت الكثير من الثركات التدريب على الإنترنت، ويرجع هذا إلى العملية و المرونة التي يتمتع بها، سو اء مَن يعطي التنريب أو مَن يتبّع ذللك التدريب، ومن مميزات هذا النوع، لا لا تحتاج المنظمة إلى حجز مكان مادي يستو عب جميع العاملين، ويسهل مشاركة العاملين، كما يمكن للعاملين الاخول إلى المحتوى من أي مكان وفي أي لحظة كانت.

5-6-1-2 ورش العمل. إجر اء الورشات أو المحاضر ات يعتبر أسلوباً شائعاً تقوم به أغلب المنظمات منذ عدة سنوات، عادة ما تكون عبارة عن محاضرات موجزة تركز على موضوع معين، ويتم إدارتها بواسطة أنخاص يتمتعون بالمعرفة العميقة في الموضوع ومن الثنائع أن تقوم المنظمات بتحضير هذا النوع من من منيرة التدريب للتعامل مع مو اضيع تشمل عدد أكبر من العاملين في مختلف المستويات التنظيمية.

6-6-1-2 نبادل المهام. تقوم فكرة تبادل المهام و الوظائف على جعل العاملين يتعلمون ويمارسون مهام أخرى خلال فترة زمنية محددة يتيح هذا الأسلوب تعزيز أهمية التناوب الوظيفي في جميع مر احل العمل، بالإضافة إلى ذللك يعتبر هذا التدريب أحد أنو اع التدريب في المنظمات التي تحفز على أهمية روح الفريق داخل المنظمة و وشناركة المعارف و الخبر ات بين العاملين.

7-6-1-2 أسلوب الألعاب. هو تطبيق عناصر اللعبة وتقنيات التصميم الرقمي للألعاب في تحقيق أهداف وحل مشاكل في ميادين أخرى خارج سياق الألعاب مثل الإعلام والتسويق والتعليم، ويستخدم التدريب 
باستخدام الألعاب خاصية الديناميكية التي تتمتع بها الألعاب في مجالات وسياقات أخرى للتحفيز على التفاعل و الارتباط، و التعلم بين أعضاء الفريق وهي طريقة فعالة بحيث تثير فضول و اهتمام العاملين.

7-1-2 مر احل العملية التدريية. تعتمد عملية التدريب على مكونات أساسه والتي هي في حد ذاتها خطوات التدريب، تتكون من مر احل منطقية ومتتابعة كما يعبر عنها الثنكل رقم (1/2)، وتتقسم العملية التدريبية الى ستة مر احل وسوف يتم شرحها في النقاط التالية.

تحديد الاحتياجات التدريبية

تنفيذ البرنامج التدريبي

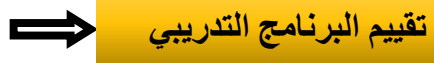

تقيم أثر التدريب

الثكل رقم (1/2) مر احل العملية التدريبية

المصدر: بتصرف الباحثة من المر اجع الأساسية ماهر،(2005) وحمزة،(2014).

1-7-1-2 تحديد الاحتباجات التدرييية: وهي العملية التي تحدد مشكلات الأداء أو المشكلات الموجودة

\section{في الوظيفة.}

2-7-1-2 نصميم الخطة التدريبية: في حال الاتفاق على وجود مشكلة أو فجوة في الأداء، يتم البدء في تصميم خطة تدريية وتحديد أهداف البرنامج بما يتناسب مع أهداف المنظمة وتحديد الفئة المستهدفة ومن

$$
\text { ثم اختيار الأساليب المناسبة لها. }
$$

3-7-1-2 إعداد البرنامج التدريبي. وفق الاحتياجات التي تم تحديدها.

4-7-1-2 تنفيذ البرنامج التدريبي. و ويتم من قبل إدارة الموارد البشرية الخاصة بالمنظمة.

5-7-1-2 تقييم البرنامج التدريبي. يتم تقييم البرنامج و المتدربين في نهاية البرنامج التدريبي.

6-7-1-2 تقييم أثر التدريب. يتم تقييم ما اكتسبه المتدرب من البرنامج التدريبي الذي التحق به ومدى

$$
\text { تطبيق ما تعلمه في وظيفته، وهي مرحلة تأتي بعد ثلاثة شهور و أكثر. }
$$


8-1-2 تحديد الاحتياجات التدرييية. بمكن البدء بالقول بأن الحاجة للتدريب تظهر بسبب وجود قصور معين في الأداء ويعتبر تحديد الاحتياجات التدريبية العنصر الرئيسي والهيكلي في صناعة التدريب ولتوضيح هذه الفكرة سنتعرف على الاعتبار ات التالية (بلال،2011) (ماهر 2005)

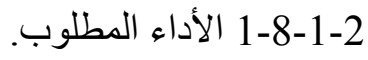
2-8-1-2 2-2 - 2-2 الأداء الفعلي. 3-8-1-2 الفرق بين الأداء المطلوب و الفعلي أو ما يسمى بالقصور. 4-8-1-2 ويمكن التعبير عن هذه العلاقة في المعادلة التالية في الثكل (2/2).

\section{القصور في الأكاء = الأداء المطلوب - الأداء الفملي}

الثكل رقم (2/2) مر احل العملية التدريبية

المصدر: بتصرف الباحثة من المراجع الأساسية ماهر،(2005) وحمزة،(2014) 2-1-8-8 ويرجع القصور في إمكانيات الأداء لعدة أسباب من أهمها، سوء تصميم الوظائف و عدم توفر الإمكانيات والمو ارد لأداء

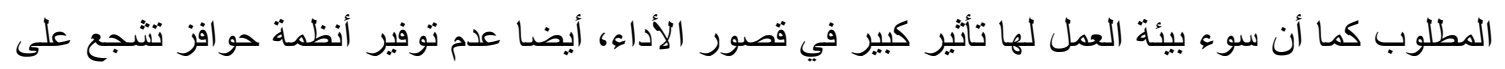

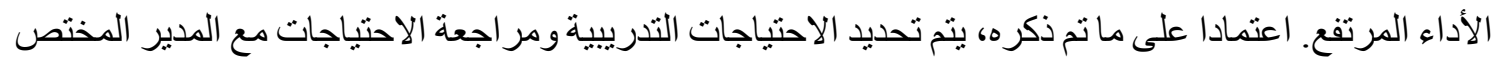
لمعرفة ما يحتاجه الموظفون لأداء العمل ومطابقتها مع أهداف الإدارة والهدف الرئيسي للمنظمة، ثم يقوم المديرون المختصون بإرسال هذه الاحتياجات الى إدارة الموارد البشرية ثم تقوم إدارة الموارد البشرية بدر اسة اهنة

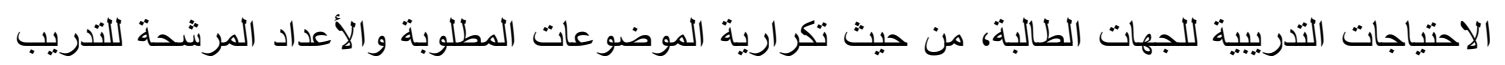
و إمكانية التدريب الداخلي أو الخارجي والتكلفة التقديرية، ومقارنتها بالميز انية المعتمدة من قبل الإدارة العليا لتدريب الموظفين.

1-5-8-1-2 تصميم الخطة التدرييية و إعداد البرنامج التدريبي. يلي تحديد الحاجة إلى التدريب تصميم برنامج التدريب الذي يفي هذه الحاجة، ويتضمن تصميم برنامج التدريب عدة موضو عات أهمها تحديد المحتوى إنى التدريبي، ثم تحديد أساليب التدريب، والأدوات المساعدة فيها، و أيضاً تحديد المدربين و أخير اً وضع نظام لتطبيق

$$
\text { ومتابعة برنامج (بدير، 2017). }
$$

2-5-8-1-2 تحديد المحتوى التدريبي. فتعني الحصيلة المقدمة للمدربين في شكل دليل يحتوي الدروس و القراءات. ويستخدم هذا الدليل كمرجع للمتدربين لاستذكار ومر اجعة المادة العلمية لبرنامج التنريب ويجب أن تكون البرامج متتوعة ومتجددة وتتناسب مع طبيعة المتدربين من حيث مستو اهم وخلفياتهم العلمية والعملية و المهام الوظيفية التي يقومون بها. 
3-5-8-1-2 تحديد أساليب التدريب. يتم اختيار الأساليب التدريبية كالتقنيات السمعية والبصرية و الوسائط المتعددة وتمنيل الأدو ار ودر اسة حالة و غير ها ليتلاءم مع تصميم البرامج التدرييية.

4-5-8-1-2 تمثيل الأدوار. يقوم المدرب بعرض مشكلة ثم يعطي المتدربين مثال عملي على أن يقومو ا بتنفيذه أي تقليد الو اقع وتدرييهح على مو اجهته ونتناسب هذه الطريقة مع حالات معينة مثل مواجهة العملاء و إدارة المقابلات الثخصية و التدريب و العلاقات العامة.

5-5-8-1-2 در اسات الحالة. يتم عرض المتدربين لحالات من و اقع العمل، ويقوم المتدربين بتتاول أبعادها من حيث المشاكل و أسبابها و الحلول المتوفرة وتقييم البدائل المختلفة وهيا لا تتناسب مع بعض المندربين كما أن البعض بيتقاعس في تحضير ها.

6-5-8-1-2 تحديد المدربون. يعتبر المدرب أحد أضلاع المثلث التدريبي الهامة التي تشكل ركيزة حيوية لنجاح العملية التدريبية، فيجب أن يكون المدرب لديه القدرة بالإلمام بالمادة العلمية و القدرة على إعداد البرنامج التدريبي أن يكون حاصل على شهادات معتمدة في مجال تدريب المدربين، وضوح الصوت وصحة النطق، دقة الالتزام بالمو اعيد، لقدرة على تحمل المسئولية، القدرة على التكيف مع المواقف الجديدة.

9-1-2 مرحلة تنفيذ البرنامج التدريبي.يلي مرحلة التصميم لبرنامج التدريب، وعند مرحلة التنفيذ سو اء كان هذا البرنامج داخل المنظمة أو خارجها، فعلى مدير التدريب الإشراف على التنفيذ والتأكد من جاهزية و إمكانية تنفيذ البرنامج الذي وضعاه. تتضمن هذه المرحلة عدت أنشطة هامة وهي: 1-9-1-2 2-9-1-2 2-1أتكد من مكان إقامة التدريب.

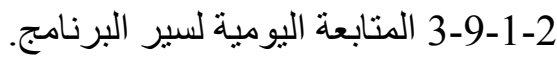
4-9-1-2 ضرورة إثر اك الرؤساء مع المرؤوسين في بر امج التدريب. 5-9-1-2 نوفير التغذية العكسية للمتدربين وتثجيعهم للاستمر ار بالسلوك المرغوب. 10-1-2 مرحلة تقييم البرنامج التدريبي. إن عملية متابعة وتقييم التدريب عملية مستمرة،

يقصد بها التأكد من أن البرنامج التدريبي يتم تنفيذه دون انحر اف عن الهدف المنشود، و إذا كان هناك معوق ينم التنخل لإزالته ليكتمل سير العملية التنريبية. يجب الأخذ بالاعتبار أن تقييم العملية التدريبية وقياس أثر البرنامج التدريبي على أداء المنظمة وتزويد الإدارة العليا و المسؤولين بشكل دوري بكل ما يتعلق بهذا الخصوص الخص أمر هام جداً لمسؤولي التدريب بالمنظمات لتقديم البراهين والأدلة على أن التدريب هو استثمار وليس هدراً

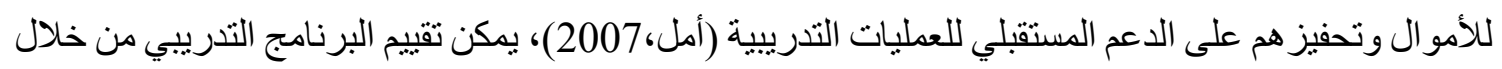
نموذج (كيرك باتريك) الذي قام بتقسيم عملية تقييم البرامج التدرييية إلى 4 مستويات مرتبطة ارتباطاً قوياً مع مع بعضها البعض وتزداد تعقيداً وتكلفة عند الانتقال من مستوى إلى آخر (الزهر اني،2019). 
1-10-1-2 مستوى رد الفعل. يتم فيه تقييم ردود أفعال المتدربين ومعرفة انطباعهم أثناء التدريب.

$$
\text { 2-10-1-2 مستوى التعلم. تقييم مدى تعلم المتدربين من محتوى البرنامج التدريبي. }
$$

3-10-1-2 مستوى السلوك. تقييم مدى قدرة المتدربين على نقل ما تدربو ا عليه الى أماكن عملهم.

4-10-1-2 مستوى النتائج. تقييم وقياس أثر البرامج التدرييية وماذا حققت النتائج الفعلية للبرنامج.

11-1-2 تقييم أثر التدريب. يعد تقييم أثر البرنامج التدريبي المرحلة الأخيرة من مر احل التدريب؛ لاستيضاح

من ردود أفعال المشاركين في الدورات التدريبية، ومدى رضاهم في العطلية التدريية ومدى الاستفادة وفاعلية التدريب، أي هي المخرجات النهائية لعملية التدريب ككل و التي نُفذ التدريب من أجلهاو هي التأكد من أن الأهداف التي تم وضعها للفئة المستهدفة قد تم تحقيقها وتمت استفادة المستهدفين من التدريب.

12-1-2 مر احل العملية التدرييية وفق نموذج (ADDIE). هو نموذج تم تطويره من قبل القوات الجوية الأمريكية عام 1970 وكان هناك نموذج اسمه ISD تعلق بمر احل التعلم، وفي عام 1970م طورته القوات الجوية الأمريكية لنموذج ADDIE ويتكون النموذج من الخطوات الخمس التالية.

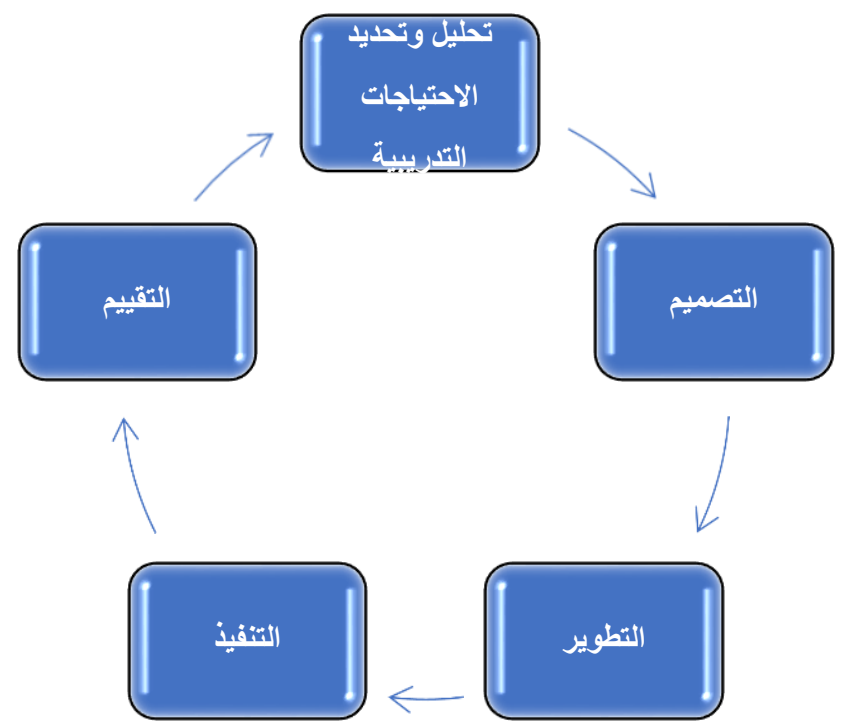

شكل رقم (3/2) نموذج ADDIE، المصدر : SHRM وبتصرف من الباحثة.

جدول (1/2) المرحلة الأولى: تحليل الاحتياجات التدريبية

\begin{tabular}{|c|c|c|}
\hline ل لمات التالية & تحليل الاحتياجات & أو ما يسمى \\
\hline تحليل المنظمة & تحليل الوظيفة & تحليل الفرد \\
\hline
\end{tabular}




\begin{tabular}{|c|c|c|}
\hline 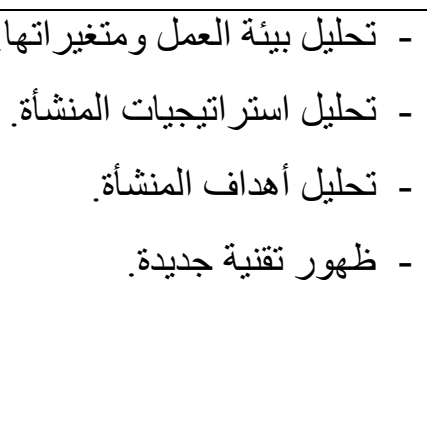 & - - تحليل ـ - تحليل و الوصف الوظيفي. & 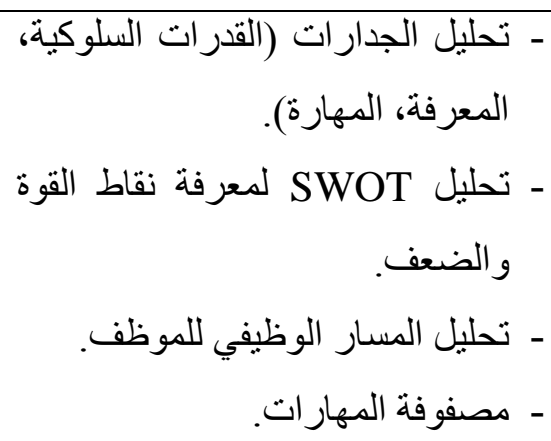 \\
\hline
\end{tabular}

\section{جدول (2/2) مرحلة التصميم و التطوير والتنقيذ}

\begin{tabular}{|c|c|c|}
\hline المرحلة الر ابعة التنفيذ & المرحلة الثالثة التطوير & المرحلة الثانية التصميم \\
\hline 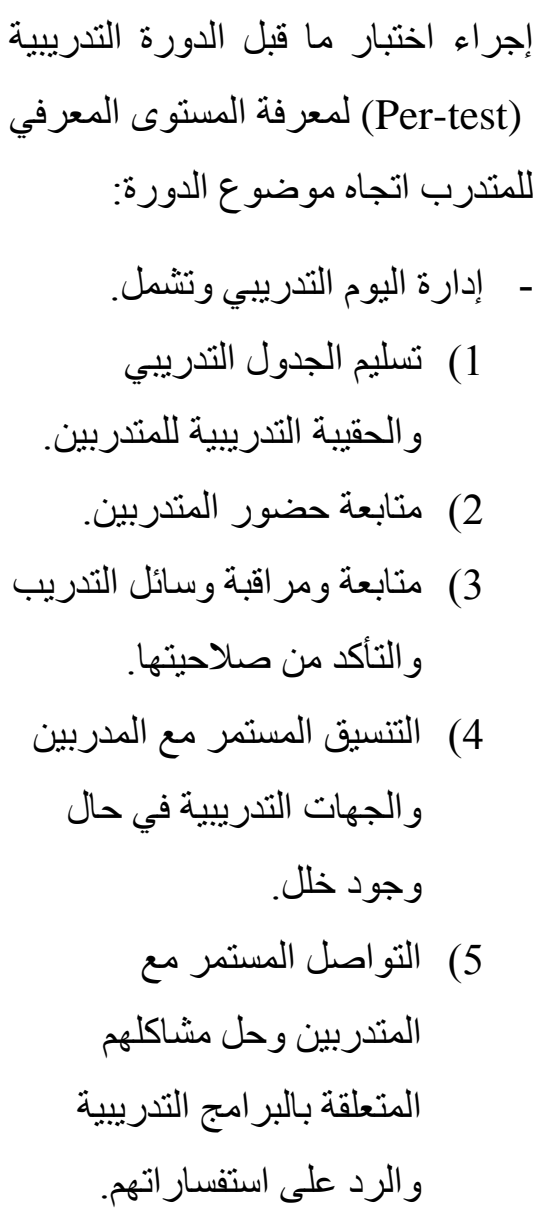 & 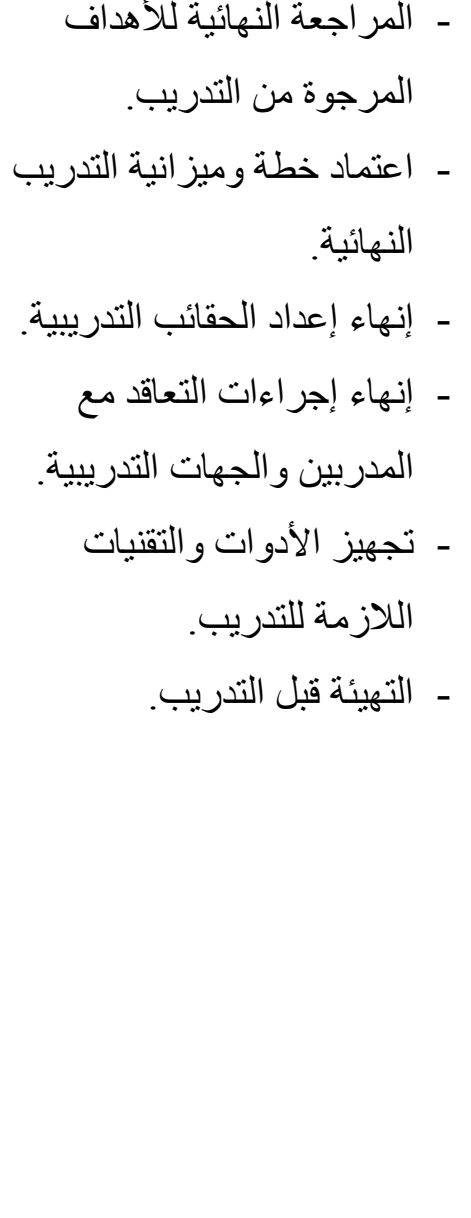 & 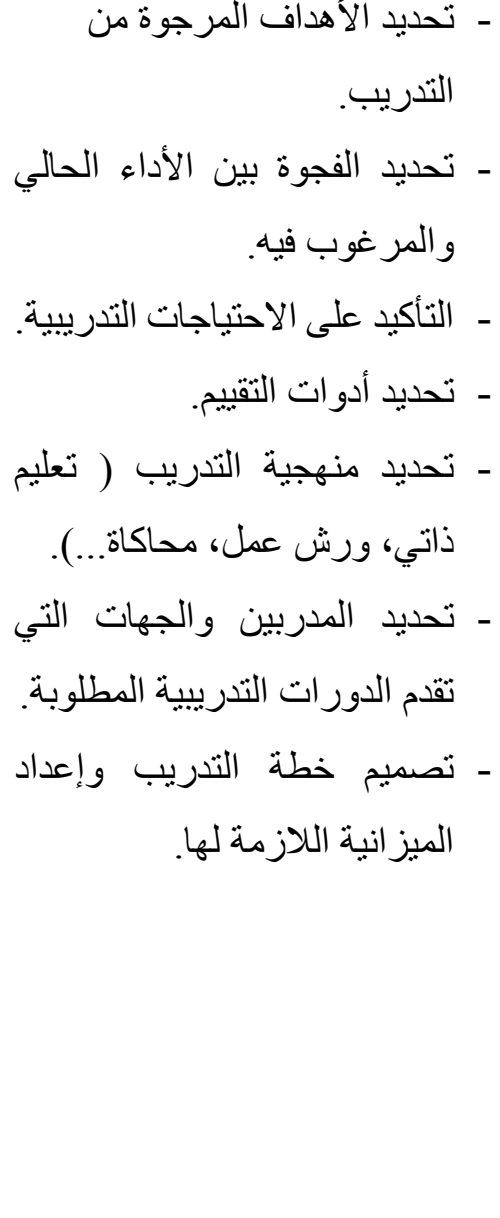 \\
\hline
\end{tabular}




\section{جدول (3/2) مرحلة التقييم}

\begin{tabular}{|c|c|c|c|}
\hline لعائد من التدريب من خلال ه مسنويات & قياس & لحل ونتمثل في قياس العائد من التدريب حيث الخامسة والأخير & 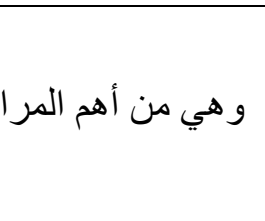 \\
\hline طرق جمع البيانات & & ما يتم تقييمه & المستوى \\
\hline 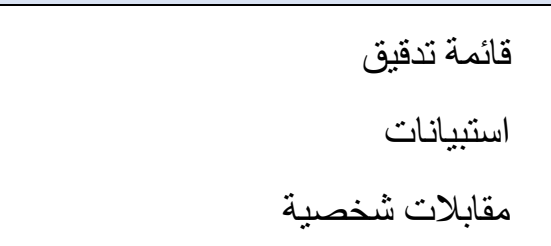 & , & شعور المتدربين حول البرنامج التدريبي & رالمستوى الأول/ \\
\hline 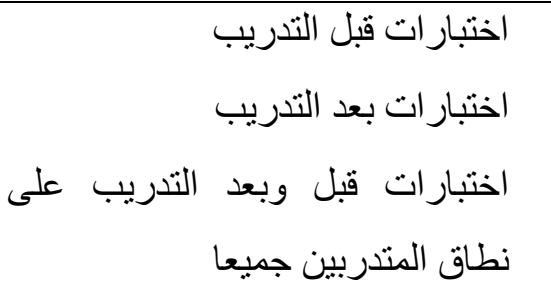 & 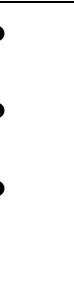 & 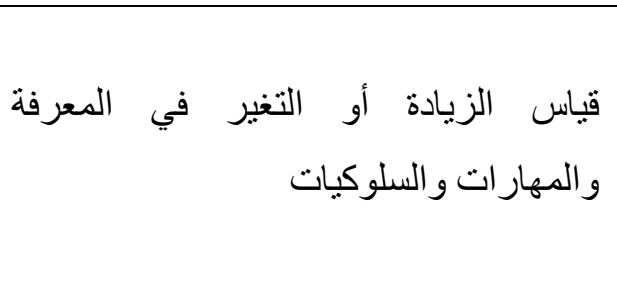 & المستوى الثاني/ \\
\hline 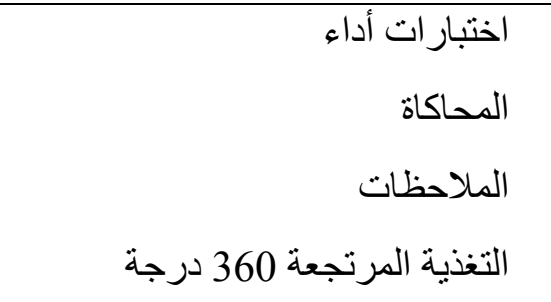 & 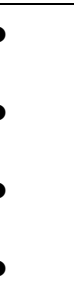 & 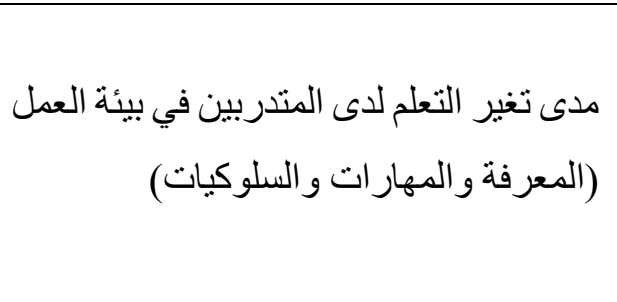 & المستوى الثالث/ \\
\hline 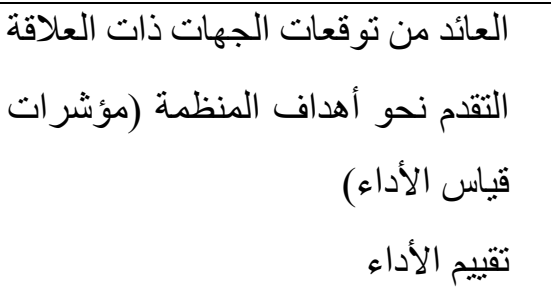 & D & و وأهداف مدى نأثنير البرنامج التدريبي على أداء & النتائج \\
\hline \multicolumn{3}{|c|}{ قياس العائد من الاستتمار } & العسائد من التدريب الخامس/ \\
\hline
\end{tabular}

13-1-2 معوقات التدريب. من المؤكد أن العملية التدريبية لا نسير بصورة مرضية و إنما نواجهها الكثير من التحديات و المشاكل، وبما أن التدريب وسيلة لتحسين الأداء وأن تطويره وتحسينه هو الغاية من التدريب، سوف

$$
\text { نذكر بعض المعوقات التي تو اجهاه. (صديق،2003): }
$$

1-13-1-2 عدم وجود علاقة وثيقة بين الدّورة الثّدريبية والعمل؛ إذ نتوجّه الكثير من المؤسسات إلى عقد دورات تدريبية للأفر اد فقط لمجرّد استهلاك المبز انيّة الخاصّة بالتّريب، بغضّ النظر عن الدورات المنعقدة

$$
\text { و أهميتّها وفائدتها. }
$$


2-13-1-2 إهمال الجانب العمليّ من الدورة التّريبيّة؛ حيث من الممكن أن تقتصر معرفة المدرّب فقط على الجانب النظريّ للموضوع؛ مع فقدانه للخبرة العمليّة في موضوع التّدريب ما يؤدي إلى إفثـال الدورة. 3-13-1-2 المحسوبيّة في اختبار المتدرّبين؛ حيث يُنتَّى المتدرّبون وفقاً لأهو اء المدير وليس بما يَتناسب مع حاجة العمل الفعليّة.

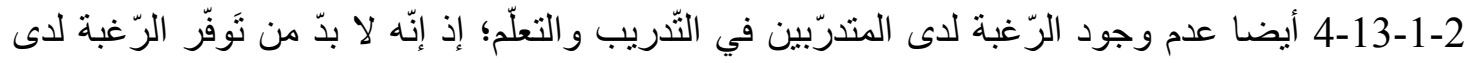

$$
\text { الأفر اد للتدرّب قبل الثروع به. }
$$

5-13-1-2 سوء المادّة التّربييّة؛ حيث تفتقر بعض الدّورات التّريبية إلى إحداث أيّ تغيير أو تطوّر في مهار ات الأفر اد وقدر اتهم، لذلك تُعدّ الدّورة التدريبيّة سيئة. 6-13-1-2 عجز المدرّب عن إيصال المعلومات أو تتمية المهارات، لذلك قد تحدث فجوةٌ كبيرة بين المُدرّب و المتدرّب وما تهدف إليه الدّورة التّريبية.

7-13-1-2 عدم اهتمام المشرفين و القائمين على التّدريب بالتّريب و المتدرّبين. سوء بيئة العمل؛ حيث تفتقر إلى مساعدة المُتدرّبين على تطبيق ما اكتسبوه من معلومات ومهار ات. (عبد الرحمن، 2017). 14-1-2 عو امل نجاح التدريب. يجب أن تر اعي الإدارة لنجاح التدريب، عو امل أساسية عند تصميم بر امجها، من

$$
\text { أهمها (نصر الله، 2002): }
$$

1-14-1-2 الاحتياجات التدريبية التي يصدم البرنامج من أجلها.

2-14-1-2 نو عية المتدربين و عددهم، ومستو اهم الوظيفي وطبيعة أعمالهم.

3-14-1-2 خصائص السلوك الحالي، وطبيعة السلوك المستهذف.

$$
\text { 4-14-1-2 الإمكانيات المتاحة و الوقت و التكاليف. }
$$

5-14-1-2 تحديد الأسلوب التدريبي المناسب، و الوسائل التعليمية، و التدريبية.

6-14-1-2 على الإدارة العليا تبني فكرة التدريب على أنها ضرورة ملحة ومستمرة تهدف إلى تطوير العنصر

$$
\text { البثري. }
$$

7-14-1-2 أن تلقى العملية التدريبية المساندة و الدعم المالي من قبل الإدارة العليا.

8-14-1-2 أن يسبق تحديد البرامج التدرييية دراسات لو اقع المؤسسة واحتياجاتها الفعليـة و الاحتياجات الفردية للعالمين. 
9-14-1-2 أن يتم التخطيط لنشاطات التدريب بشكل مستمر بإتباع الأسلوب الثمولي الذب يولي اهتماما لكافة عناصر المدخلات و العمليات و المخرجات و التغذية العكسية. 10-14-1-2 كما يجب التنويع في الأساليب المستخدمة في التقييم لقياس أثر ونتائج التندريب و التكلفة و العائد بشكل دقيق. 11-14-1-2 كما عليها أن تعتمد معايير محددة في خطة التدريب، يستعان بها في مقارنـة النتائج المحققة مع المستهدفة في الخطة.

12-14-1-2 إعطاء الأولوية في التدريب للوظائف التي يصعب شغلها إلا عن طريق التعيين من الخارج. 13-14-1-2 كما يجب أن يتسم التدريب بالثمولية بحيث يأخذ بعين الاعتبار كافة الوظـائف المختلفة في المنظمة سو اء الفنية و الإدارية و الكتابية، وتعطى الأولويات طبقا للإمكانيات المالية و التوجهات للمنظمة. 14-14-1-2 تحفيز المتدربين. 15-14-1-2 الإفادة من التقييم في محاولة لإدخال التعديلات بما يزيد مـن فاعليـة بـر امج التدريب.

15-1-2 البر امج التدريية في البنك الأهلي التجاري السعودي. في العقد الأخير اتجهت المصارف الى زيادة الإنفاق في مجال التدريب و النطوير المستمر لر أس المال البشري ويرجع السبب في ذللك الى مو اكبة التطور ات و التحو لات الاقتصادية الكبيرة التي تشهدها المملكة مع رؤية 2030. اختارت الباحثة البنك الأهلي التجاري لتميز البرامج التدريبية في البنك الأهلي التجاري عن غيرة من المصارف السعودية كما أن من الأهداف الاستر اتيجية للبنك الاهتمام بالمورد البشري " أن يكون الاختبار الأول للموظفين "، وهذا يعكس مدى اهتمام و الاستثمار في المورد البشري لديهم. 1-15-1-2 أكاديمية البنك الأهلي التجاري للتدريب. المشروع يعكس اهتمام البنك بالعنصر البشري وحرصه الذي يعتبر ر افداً رئيسياً للمساعدة في دفع عجلة برنامج تطوير الكفاءات السعودية وتأهيل الكو ادر للعمل في المصرف والإسهام في تتمية المورد البشري للقطاع المصرفي، وحرصه على نوفير بيئة العمل المناسبة لكل من العاملين والعملاء وان

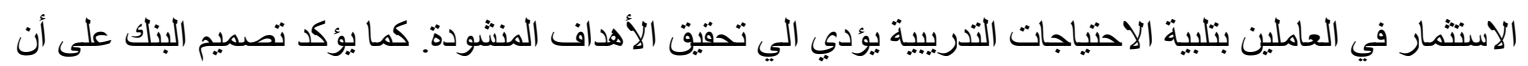
تو اكب خدماته أحدث النظم المصرفية التي من شأنها الارتقاء بالصناعة البنكية في المملكة وان مبنى الأكاديمية يتألف من 4 أدوار وتم تصميمه لبيتو عب حاجة البنك المتز ايدة لمر افق تدرييية حديثة حيث يحتوي المبنى على 7 قاعات تتسع كل منها لخمسة و عثرين مندرباً إضافة لقاعة رئيسية تحاكي نموذج الفروع الجديدة وتستهدف تطوير المهارات العملية و الفنية لمنسوبي البنك على مفاهيم الخدمة الجديدة.

2-15-1-2 برنامج وسام الأهلي. لأن برنامج وسام الأهلي تنافسي بطبيعته، فإنه قد صُمم ليحقق ميزة تنافسية تجعلنا نرتقي بخدمة العملاء الى أعلى المعايير ونتفوق على منافسينا. 
ومن المتوقع أن يحقق وسام الأهلي نجاحاً كبيراً لأن غايته هي إعداد مصرفيين حقيقيين يتمتعون بالمهارات المناسبة لتعزيز رضا العملاء وتلبية احتياجاتهم، ويتضمن البرنامج تدريباً مستمراً طيلة العام. من العناصر الأساسية للبرنامج:

$$
\begin{aligned}
& \text { برنامج تعليمي وتدريبي منكامل } \\
& \text { دور ات تدريبية وتقنية تحت إثر اف وقيادة مدربين أكفاء } \\
& \text { تدريب عملي داخل الإدار ات زيار ات لوحدات العمل }
\end{aligned}
$$

تقييم تفصيلي لكل مرشح، ومشاركة الإنجاز ات و المجالات من أجل مزيد من التطوير أنشطة مختلفة تتضمن بناء الفرق، والتطو ع في أعمال مجتمعية من خلال بر امج المسؤولية الاجتماعية

$$
\text { و الاستدامة بالبنك، بالإضافة إلى الندوات الإبداعية }
$$

2-15-15-2 برنامج التأهيل المصرفي. يوجد فرص متميزة للالتحاق في برنامج التأهيل المصرفي للجامعيين السعوديين من حملة البكالوريوس في تخصصات إدارة الأعمال، أنظمة، ترجمة إنجليزي، الإدارة المالية، التسويق، إدارة الأعمال الدولية، الاقتصاد، المحاسبة، ونظم المعلومات الإدارية. 1-3-15-1-2 أهداف البرنامج. يهدف البرنامج لإعداد الكفاءات الإشر افية السعودية في البنك الأهلي التجاري، حيث يتلقى المتدرب أفضل فرص التدريب العالي والمتقدم، بالإضافة إلى التدريب على رأس العمل في كافة

$$
\text { مجالات الأعمال المصرفية و المهار ات الإشر افية. }
$$

2-3-15-1-2 المز ايا. يمنح المتدرب مكافأة مجزية خلال فترة التدريب ويعين بعد اجتياز البرنامج التدريبي على التى إحدى وظائف الشركة الأساسية، ويمنح كافة المزايا والبدلات الممنوحة للموظفين.

4-15-1-2 برنامج أكاديمية تقنية المعلومات. بهدف استقطاب الكفاءات السعودية الثابة و إعدادها لتولي المسؤوليات العملية في مجال خدمات تقنية المعلومات في البنك، حيث إن برنامج أكاديمية تقنية المعلومات هو أحد الأمثلة التي تجسّد الأهمية التي يوليها البنك الأهلي لتشجيع وتطوير وتأهيل الكوادر الوطنية في شتى التخصصات ومجالات العمل المصرفي، ومن أهمها تقنية المعلومات والتي تعنبر العمود الفقري

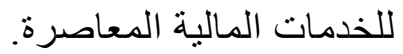

يتكوّن برنامج أكاديمية تقنية المعلومات من ثلاث مر احل تدريبية أساسية ويستخدم وسائل متنوعة في التدريب الذاتي و التفاعلي. تتمثل المرحلة الأولى بـ 16 أسبوع تدريب تقني تقدمها شركة إتش بي (HP)؛ تليها المرحلة الثانية بـ 3 أسابيع تدريب على المهار ات الثانوية اللازمة للتوظيف، ثمّ 4 أسابيع من التدريب العملي على رأس العمل في المرحلة الثالثة والنهائية يتم خلالها إعداد المتدربين للانضمام للبنك كموظفين بدو ام كامل موز عين على أربع مسار ات مهنية بحسب اهتماماتهم وتميّز هم في كل مجال، سو اءً في خدمات تقنية المعلومات، التطوير، إدارة المخاطر، إدارة المشاريع، 
تتم عملية اختبار المتدربين المرشحين للبرنامج ضدن نهج مدروس بستهدف الى استقطاب أصحاب الأداء الأكاديمي المتميز، وبعد عملية تدقيق للتأكد من أن جميع المتقدمين قادرون على خوض البرنامج وفهر مئر محتو اه و استكماله بنجاح وتحقيق أهدافه.

$$
\text { 5-15-1-2 الدورات المتخصصة، (في بعض أقسام البنك). }
$$

$$
\text { • برنامج إدارة تحليل المخاطر مدة البرنامج } 10 \text { أيام. }
$$

• برنامج استر اتيجية التحويل ( و هي دور ات متخصصة في إدارة العلاقة و القيادة و التو اصل) و هو

$$
\text { مكون من } 3 \text { مر احل كل مرحلة } 3 \text { أيام . }
$$

• الثهادة المهنية في أساسيات مصرفية الأفر اد هذه الدورة منطلب إجباري من مؤسسة النقد لجميع

$$
\text { موظفي قطاع الأفراد. }
$$

• أطلاق مجموعة من الحلول التدريبية في التطوير الثخصي (مثل مهار ات الاتصال، بناء فريق

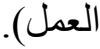

6-15-1-2 برنامج رو اد الأهلي. يقدم هذا البرنامج المبتكر تدريباً عملياً للخريجين الجدد مصحوباً بتدريب نظري في مختلف إدارات البنك لمدة ^ أثنر. وبعد انتهاء الفترة التدريبة بنجاح، يعين المتدرب موظفاً بدوام كامل في القسم الأكثر ملائمة للطرفين، ويرتبط برنامج الرواد بأهداف بعيدة المدى يأتي على رأسها استقطاب الخريجين

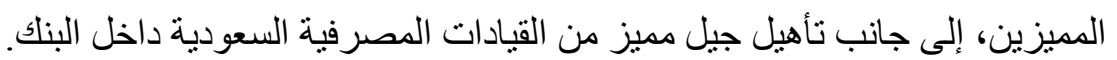

7-15-1-2 برنامج التدريب التعاوني. يتيح البنك الأهلي فرص التدريب أمام طلبة الجامعات والمعاهد الذين يحتاجون إلى استكمال منطلباتهم الدر اسية بالتدريب في بيئة عمل حقيقية، والتدريب على مهار ات جديدة و التعرف على سوق العمل قبل الانضمام إليه بعد التخرج، تركز بر امج التدريب في البنك الأهلي بشكل رئيسي على التعريف بآلية العمل داخل أقسام البنك المختلفة. ويتم تكليف المتدربين بالقيام ببعض الأعمال، الأمر الذي يتيح لهم اكتساب روح المسؤولية و الانضباط مما يعزز فرص العمل لهم بعهد التخرج، علما بأن التقديم على برنامج التدريب التعاوني (مختصر على الجامعات/ المعاهد التي تم توقيع اتفاقية تدريب بينها وبين البنك).

2-2 جودة الحياة الوظيفية. تعد جودة الحياة الوظيفية من المواضيع الإدارية الهامة في إدارة الموارد البشرية و السلوك التنظيمي، لما لهذا المفهوم من تأثثر مباثر على الروح المعنوية للعنصر البشري وبالتالي على أداء المؤسسة. فالأفر اد الذين يتمتعون بجودة حياة وظيفية مميزة يكو ن لديهم أداء عالي،

وفي المقابل المؤسسات التي تسعى إلى الاهتمام بالعنصر البشري كونه يمثل أحد المؤثرات القوية التي تقوم عليها الميزة التنافسية بين تلك المؤسسات من خلال توفير بر امج جودة حياة وظيفية تتسم بالجودة و الفاعلية للعاملين فإنها

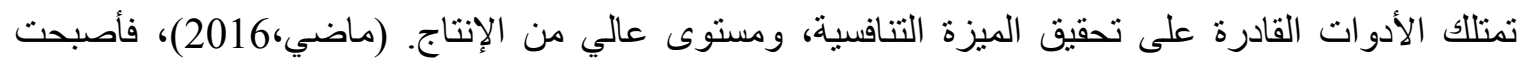
المنظمات الحديثة تركز على العلاقة بين الفرد و المنظمة، 
وتعطى أهمية كبيرة لجهد الفرد في العمل و الاعتر اف بهذه الجهود من خلال تمكين الموظف في المشاركة الإيجابية في صنع القرار، لذللك جودة حياة العمل مهم للعاملين، لأنها توفر لهم الارتياح النفسي والمادي، وتجعل العامل

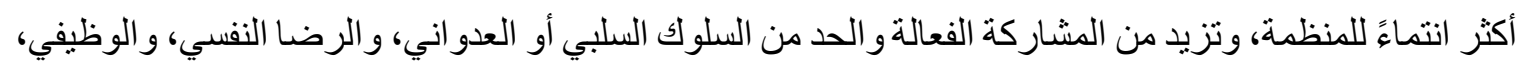
وزيادة التقة، وتحسين العلاقات بين العاملين و الإدارة، بالإضافة إلى تقليل التوتر و القلق الناتج عن ضغوط الته العمل، و الحد من الصر اع وتحسين الإنتاجية وتعزيز موقف المنظمة التنافسي(Arid and plays,2013 ).

1-2-2 مفهوم جودة الحياة الوظفية. لغة أصلها من فعل جاد، الجودة، جاد، جود، جودة، أبي صار جيدا وهو ضد الرديء (البستاني، 1998)، و اصطلاحا فالجودة هي انعكاس للمستوى النفسي وأن ما بلغه الإنسان اليوم من مقو مات الرقي و التحضر ، تعكس بلا شك مستوى معينا من جودة الحياة، ويقصد بجودة ودرجة تو افقه مع ذاته ومع الآخرين وتكوينه الاجتماعي و الأخلاقي، واختارت الباحثة بعض التعاريف الأكثر شيو عا لجودة الحياة الوظيفية

$$
\text { حسب السياق التاريخي لصدور ها. }
$$

جدول (4/2) تعريف جودة الحياة الوظيفية حسب السياق التاريخي

\begin{tabular}{|c|c|}
\hline التعاريف الأكثر شيو عا & المر اجع \\
\hline 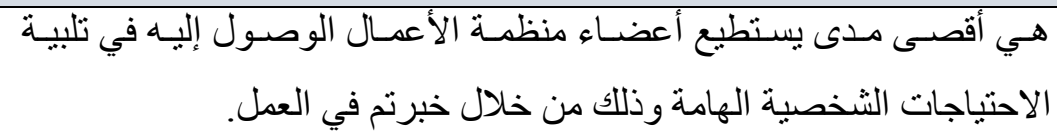 & Suttle ,1977 \\
\hline 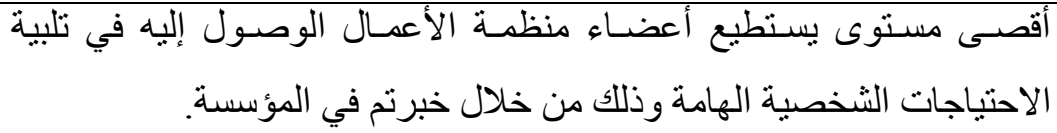 & Frederick ,1980 \\
\hline هن خي الأوضاع وبيئة العمل المفضلة للعاملين التي تـدعم وتعزز رضا العلات الموظفين & Lau\&May,1998 \\
\hline 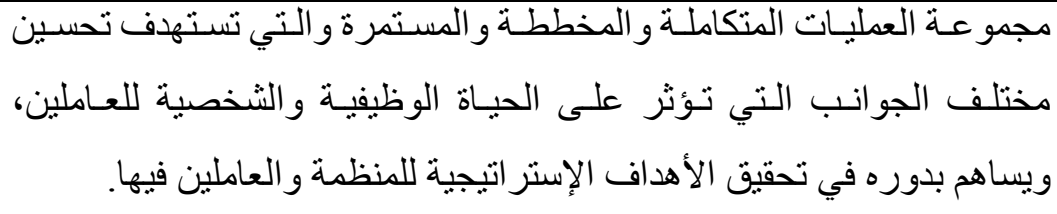 & 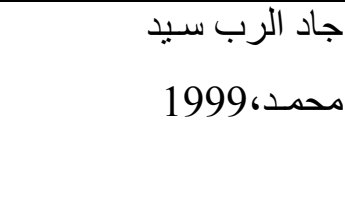 \\
\hline 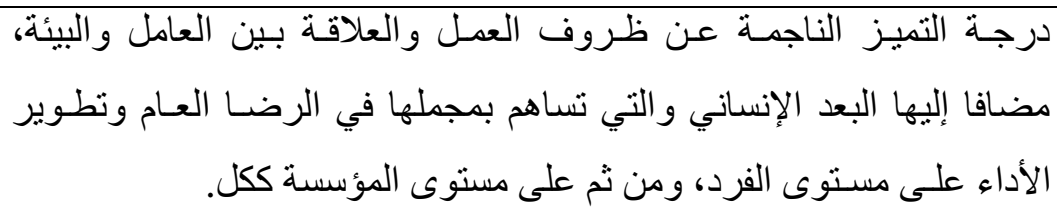 & Surya\&Shani,2013 \\
\hline الموظف فيئة العمل التي تتو افر فيها جميع العو امل المادية و المعنوية التي تتعكس على المان الوظيفي فيبذل اقصى جهد لخدمة المنظمة. & البربري،2016 \\
\hline
\end{tabular}


2-2-2 أبعاد جودة الحياة الوظيفية. لقد اختلف الباحثين في تحديد ووضـع أبعـاد جودة الحيـاة الوظيفيـة وهذا الاختلاف راجع إلى أهداف الدراسـة التي أنشئت من أجلها در اسة كل منهم فقسم بعض الباحثين أبعاد جودة الحياة الى عدة جو انب على سبيل المثنال (السالم،2009) قسم أبعـاد جـودة الحيـاة الوظيفيـة إلى قسـين: البعد الإنسـاني ويشــل الجانب الاجتماعي والجانب المعنوي والعقلي، والبعد الاقتصادي ويشمل الرواتب وعلاج الأمر اض، فرق وجماعات العمل. (وســام محمـــ الحســي،2016 ) أختـار في دراســـه لجـودة الحيـاة

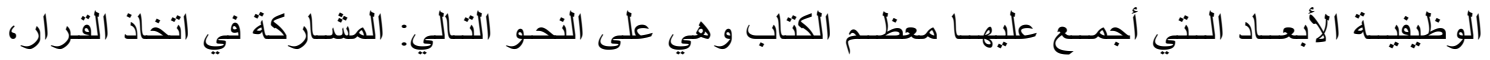
العلاقـات الاجتماعية، السـوك القيـادي و الإشـر اف على العمل، الأجور، الاستقرار و الأمن الوظيفي. أما بالنسبة للدر اسة الحالية فسيتم التركيز على الأبعاد التي ترى الباحثة أنها تفيد در استها وهي على النحو التالي:

1-2-2-2 الترقي الوظيفي. تعرف الترقية بأنها عملية إعادة تخصيص الفرد على وظيفة ذات مستوى أعلى، و عادة ما تتطوي مثل هذه الوظيفة على و اجبات، مسؤوليات، سلطات أكبر و أكثر صعوبة من و اجباته وسلطاته في الوظيفة السابقة، كما أهنا عادة ترتبط بالزيادة في الرو اتب أو الأجر. حيث أنها تلعب دور ا مهما لكل من الفرد و المنظمة، فالفرد يحقق رغبته في النمو و الترقي وتحقق المنظمة رغبتها في تحقيق التو افق بين الفرد و الوظيفة، وتحصل على أداء ورضا عالي فيمكن القول ببساطة أن الترقية هي التقدم في المنصب و الزيادة

$$
\text { في المسؤولية (الحسني،2016) }
$$

2-2-2-2 ظروف العمل الصحية. يمكن التعبير عنها بانها توفير العو امل البيئة المرضية والآمنة بمكان العمل بما يدعم رضاء العاملين. (1991,Havlovic)، و الاهتمام بشكل مستمر بالظروف المادية للعمل من إضاءة وتهوية وتوفير أدوات ومستلزمات العمل وذلك من شأنه أن يجعل العاملين يؤدون أعمالهم بارتياح نفسي مما يرفع من مستوى الرضا لديهم، وبالتالي رفع مسنوى الأداء و الإنتاجية. (عبدالرحمن ومجيد،2012)

3-2-2 أهمية جودة الحياة الوظفية. لابد من الإثارة عند الحديث عن أهمية جودة الحياة الوظيفية الى أنها ترتبط بأهم مورد لدى المنظمة إلا وهو المورد البشري، وأن الاستفادة والمنافع التي يحصل عليها العاملون و التي تعطي مؤشر ات ملموسة عند أداء وظائفه بطريقة جيدة تعتبر طريقة قياس لجودة الحياة الوظيفية لدى المنظمة. كما أن جودة الحياة الوظيفية تتمثل أهميتها في كونها استر اتيجية متكاملة لجعل المنظمة مركز جذب واستقطاب الكفاءات الميزة ويزداد فيهم الو لاء و الالتز ام لثعور هم بتكامل أهداف المنظمة مع أهدافهم.(العنزي، 2007)، عليه يمكن القول تساهم جودة الحياة الوظيفية في تحقيق عدة نتائج منها (عبطاني،2014).

$$
\text { 1. تحقيق ميزة تنافسية بجذب الكفاءات المتميزة. }
$$

2. التفوق على المنافسين من خلال حرص العاملين على تحسين الإنتاجية. 3. الحفاظ على راس المال البشري و على العاملين ذو المهار ات والخبرة. 4. إعادة هيكلة الأنشطة ليصبح العمل أكثر رضا للعاملين. 5. تقليل الصر اعات بين العاملين و الإدارة من خلال تحقيق مناخ تنظيمي تسود فيه روح التعاون. 


$$
\text { 6. ارتفاع الو لاء التنظيمي لدى العاملين. }
$$

7. تحقيق فرص نمو و التقدم من خلال الخبرات المنوفرة لاى العاملين.

يمكن القول إن غاية جودة الحياة الوظيفية هي تحقيق السعادة للعاملين وتحقيق الإير ادات و الأرباح للمالكين و أيضـا تحقيق قيمة مضافة للمجتمع من خلال تقديم سلع وخدمات تلبي احتياجاته، ولذلك فإن استقرار العاملين في المنظمة يساعد في تحقيق فرص النمو والتطور مما يعزز قدرة المنظمة على المنافسة وزيادة الرفاه الاقتصادي و الاجتماعي مما يؤثر في درجة الرضا الوظيفي للعاملين (الهيتي، 2010) (المغربي، 2009).

4-2-2 أهداف جودة الحياة الوظيفية. تتوزع مسؤولية تحقيق أهداف جودة الحياة الوظيفية بين الموارد البشرية (الموظفين) و المنظمة فلكل منهم أهدافه، فالا هنمام المنز ايد بالموظفين و الإدارة الجيدة للحياة الوظيفية لهم سيقود إلى تكوين كفاءة بشرية عالية ور اغبة في العمل، فكلما أدرك الموظفون دعم الإدارة لهم وقوة مهار اتهم وقدر اتهم وبين الفرص المتاحة أمامهم للتقدم والتدرج الوظيفي؛ كلما زاد ذلك من إخلاصهم وو لاءهم للمنظمة وشعور هم بالانتماء إليها.

1-4-2-2 يمكن إبر از اهم أهداف المنظمة من تطبيق جودة الحياة الوظيفية بالعناصر التالية (محد،،2011). 1. مقابلة احتباجات المؤسسة الحالية والمستقبلية من الموظفين في المستويات المختلفة وتزويدهم بالتوجيه

الذي يحتاجونه لتوظيف قدر اتهم لتحقيق مسار وظيفي ناجح لهم بالمنظمة يتو افق مع تطلعاتهم ومو اهبهر. 2. تقليل معدل دور ان العمل و التغيب و إصابات العمل، مما يزيد من دافعية ورضا الموظفين، ويؤدي إلى تهيئة وتعزيز القدرة التنافسية للمنظمة و إعداد قيادات مؤ هلة ومتكاملة المهار ات.

2-4-2-2 أما أهداف الموظفين من تطبيق جودة حياة العمل فيمكن حصر ها بما يأتي. 1. اختيار الموظفين للشواغر الوظيفية بما يتتاسب مع المؤهلات العلمية والعملية لهم وتتمية ومواكبة الخبر ات و القدر ات للموظفين. 2. الاستفادة من فرص الترقية و التدرج الوظيفي. 3. إنثباع الحاجات الإنسانية الأساسية والأمنية و الاجتماعية، وحاجات المكانة و التقدير وتحقيق الذات. 5-2-2 تحديات تطبيق جودة الحياة الوظيفية. على الرغم من الأثر الإيجابي لتطبيق بر امج جودة الحياة الوظيفية حسب عديد من الدراسات إلا أن العديد من المنظمات لم تنجح في الوصول إلى الأهداف المرجوة ذللك بسبب منها (البلبيسي،2012).

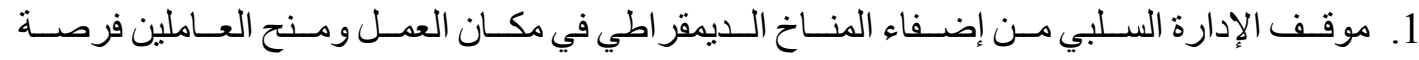
التعبــر عـن أر اءهم، إلا أن ذلك صعب التنفيذ لأن الكثير من المدر اء يعتبرون التخلي عن جزء من صداحياتهم ومشاركتها مع الآخرين بمثابة تهديد صريح لوجودهم. 


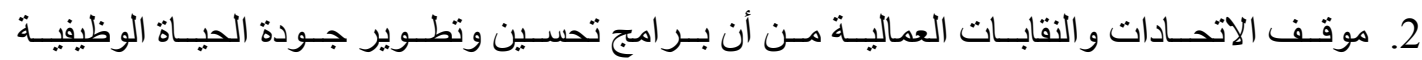
هـدفها فقـ الربحية دون دفع عو ائد ربحية للعمال،، و لإز الة هذه المخاوف يجب على المدراء الترويج لبرامج جودة الحياة الوظيفية و النتائج المرجوة منها و العو ائد المترتبة عنها للمنظمة و الأفر اد سوية.

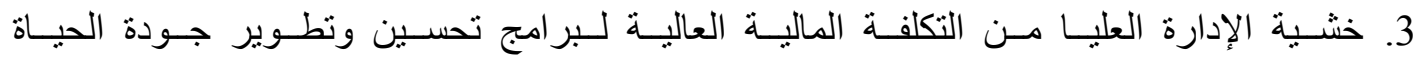
الوظيفيـة دون وجــود ضمان لنجاح هذه البر امج، ولذلك من الأفضل تطبيق هذه البر امج تدريجيا وفق ميز انيات متعاقبة تكون مدرجة في إستر اتيجية المنظمة على المدى المتوسط والطويل.

من الطبيعي لأي باحث في العلوم الإنسانية و الاجتماعية ـأو أياً كان نوع هذا البحثـ الرجوع للار اسات السابقة التي تتاولت موضوع بحثه لتجنب التكرار و الازدو اجية وتحليل نقاط التشابه و الاختلاف بين بحثه وتللك التي سبقته في نفس الموضوع، حيث قامت الباحثة بالاطلاع على أهم تلك الدر اسات التي تناولت موضوع بحتهها "أثر التدريب على جودة الحياة الوظيفية، دراسة ميدانية على العاملين في البنك الأهلي التجاري" غير أنها لم تجد در اسات مطابقة تماماً لموضوع بحثها، إلاًّ بعض الدراسات التي تتاولت الموضوع من بعض الجوانب دون التطرق إلى الموضوع بالدراسة والتحليل، عليه فقد قامت الباحثة بحصر مجموعة من الدراسات لها صلة بموضو ع البحث لتحليل أهدافها ونتائجها ومقارنتها للنتائج التي ستتوصل إليها، و هي كالآتي.

\section{1-3-2 1الار اسات السابقة}

1-1-3-2 دراسة صالح (1999). بعنوان (تقييم فاعلية البرامج التدرييية في مر اكز التدريب الخاصة من وجهة نظر المندربين: دراسة تطبيقية على المصارف التجارية الأردنية) و هدفت هذه الدراسة الى معرفة فاعلية بر امج التدريب و التعرف عليها وتحليلها في مر اكز التدريب الخاصة، لتحديد سلبياتها و إيجابياتها والتعرف الى الأثر الذي تحدثه هذه البرامج على أداء العاملين في الدصارف التجارية الأردنية ومن أهم النتائج التي توصلت إليها أن مر اكز التدريب وأيضا المصارف لا نهنم بتقييم العاملين بعد انتهاء فترة التدريب والتحاقهم بعمهم لمعرفة فائدة التدريب، وأوصت الدر اسة بضرورة قيام مر اكز التدريب و المصارف بمتابعة أداء العاملين

$$
\text { وتقيمهم بعد انتهائهم من التدريب خلال فترة زمنية معينة. }
$$

2-2-3-2 دراسة آل بشر (2004). بعنوان (تقييم بر امج التدريب في شركة سابك و أثرها على أداء

العاملين)، هدفت هذه الدراسة الى تقييم برامج التدريب في سابك لما للتدريب من آثار مهمة في عملية التنمية الثاملة، و شملت عينة الدر اسة جميع العاملين الذين خضعو الدورة التدريب الصناعي و المهني و البالغ عددهم (480) وقد نم استخدام الاستبانة لجمع البيانات، وكان من أهم النتائج التي توصلت إليها الدر اسة هناك اهتمام من قبل الإدارة بالدورات التدريبية و من حيث أهدافهاو أساليبها وتوقيت ومكان انعقاد الدورة و العمل على إيجاد نو افق بين أهداف الدورات و حاجات العمل الميداني، 
وتم استنباط عدة توصيات من أهمها تطوير البرامج التدريبية بما يناسب العمل و عدد العمالة و الاهتمام بالكادر المسؤول عن تقديم الدورات ونوفير الوسائل التدريبية الملائمة. 3-3-2 دراسة العطوى (2007). بعنو ان (أثر أساليب التدريب على فاعلية البر امج التدريبية في المؤسسة العامة للتعليم الفني و التدريب المهني في المملكة العربية السعودية)، هدفت هذه الدر اسة الى التعرف على أساليب التدريب و أثر ها على فاعلية البرامج التدريبية في المؤسسة العامة للتعليم المهني في المملكة العربية السعودية، تم استخدام استبانة مطورة لغرض جمع البيانات من أفر اد عينة الدر اسة البالغ عددهم 548، توصلت الدر اسة الى مجموعة من النتائج من أهمها أن المتوسط العام لتصورات المبحوثين لأساليب التدريب المتبعة جاءت بدرجة مرتفعة، وان المتوسط العام لتصور اتهم لمدى فاعلية البر امج التدريبية جاءت أيضا بدرجة مرتفعة، كما توصلت إلى وجود أثر لأساليب التدريب المتبعة في فاعلية البرنامج التدريبي للمندربين في المؤسسة العامة للتعليم الفني و المهني في المملكة العربية السعودية، أوصت الدراسة بضرورة تحسين بيئة التدريب، وتحسين البنية الأساسية للتندريب و اختيار المدربين من لهم خبرة في هذا المجال. 4-3-2 دراسة الزهر اني (2012). بعنوان (إستر اتيجية التدريب و أثر ها على الجدار ات السلوكية للعاملين في المصارف التجارية السعودية) هدفت هذه الدراسة إلى التعرف على الممارسات ذات العلافة بإستر اتيجية التدريب في المصارف التجارية السعودية، وأثر ها في مستوى الجدار ات السلوكية للعاملين فيها، تكون مجتمع الدراسة من (12) مصرف تجاري وعينة عشوائية عددها (108) و تم استخدام الاستبانة كأداءه لجمع المعلومات.ومن اهم النتائج أن مستوى ممارسة المديرين عينة الدر اسة في المصارف التجارية السعودية لأنشطة التدريب ومر احل العملية التدريية كان منوسط نسبيا، وجود علاقة ارتباط إيجابية قوية ذات دلالة إحصائية بين درجة ممارسة المديرين عينة الدراسة في المصارف مجتمع الدراسة لكل من أنشطة وخطو ات بناء إستر اتيجية التدريب، ومر احل العملية التدريبية من مدخل استر اتيجي، وتبني و استخدام التكنولوجيا الحديثة في تطبيق ذللك، وبين مستوى الجدار ات السلوكية للعاملين فيها،، وقد خلصت الدر اسة إلى جملة من التوصيات في ضوء نتائجها، أبرزها ضرورة ممارسة المصارف التجارية السعودية لوظيفة التدريب ومر احل العملية التدريية من مدخل استر اتيجي، وتفعيل دور التكنولوجيا الحديثة في تطبيقها، وكذلك زيادة دعم ومساندة الإدارة العليا في هذا المجال

لتحسين مستويات الجدار ات السلوكية للعاملين فيها.

ه Shakeel \& lodh(2015) بعنوان (أثر التدريب والتطوير على أداء الموظفين)، هدفت هذه الدر اسة الى قياس أثر التدريب و التطوير على أداء العاملين في البنوك التجارية في باكستان، وتم اتباع المنهج الوصفي التحليلي وتوزيع 200 اسنبانة، وظهرت النتائج أن هناك علافة إيجابية بين التدريب و التطوير و أداء الموظفين.

6-3-2 دراسة الغول (2015). بعنوان (جودة الحباة الوظيفية على أداء العاملين في المصارف الإسلامية الأردنية) تهدف الدراسة الى بيان أثر جودة الحياة الوظيفية على أداء العاملين في المصارف الإسلامية الأردنية من وجهة نظر العاملين، وتكون مجتمع الدر اسة من عينة عشو ائبة من العاملين في المصارف الإسلامية الأردنية

$$
\text { في (3) مصارف وتم استخدام استبانة لجمع البيانات، }
$$


توصلت الدراسة الى عدد من النتائج من أهمها يوجد اثر ذو دلالة إحصائية لجودة الحياة الوظيفية بأبعادها ( تصميم الوظائف، التعويضات، التكامل الاجتماعي) على أداء العاملين في المصارف الإسلامية الأردنية من وجهة نظر العاملين فيها، ويوصي الباحث المصارف الإسلامية الأردنية بزيادة الاهتمام بأبعاد جودة الحياة الوظيفية بتصميم وظائف محفزة على الأداء و اعتماد احدث الأساليب لتطوير قدرات العاملين. 7-3-2 دراسة محمد إيهاب (2016). بعنوان (أثر جودة الحياة الوظيفية على الأداء التنظيمي: دراسة تطبيقية على قطاع البنوك) تهدف الدراسة إلى التعرف علي أثر جودة الحياة الوظيفية على الأداء لتنظيمي، من خلال دراسة تطبيقية على قطاع البنوك وأشنارت نتائج الدراسة إلى وجود تأثير ذو دلاله معنوية لجودة الحياة الوظيفية على الأداء التنظيمي، حيث يوجد تأثير ذو دلاله إحصائية ومعنوية لجودة الحياة الوظيفية على الأداء التظظيمي في قطاع البنوك المصري، وان هناك علاقة ارتباط بينهما اتجاهها طردي، فكلما زادت جودة الحياة الوظيفية زاد الأداء التظظيمي بشكل إيجابي وأوصت الدر اسة بضرورة العمل بشكل جدي على تطوير وتحسين النظم الإدارية في قطاع البنوك والاهتمام بالتخطيط والتنظيم ووضع الأسس والقو اعد العامة التي تحكم عملية الانتقال إلى عصر التنافسية من خلال الاهتمام بالعنصر البشري. 8-3-2 دراسة البياري (2018). بعنوان (جودة الحياة الوظيفية وأثرها على الالتزام التنظيمي لموظفي لهي وزارتي العمل و التنمية الاجتماعية في قطاع غزة) هدفت الدارسة للتعرف على جودة الحياة الوظيفية وأثرها على الالتزام التنظيمي لموظفي وزارتي العمل و التنمية الاجتماعية بقطاع غزة. وقد تم استخدام المنهج الوصفي التحليلي للدارسة، حيث تم تصميم استبانة الدر اسة كوسيلة لجمع البيانات اللازمة وتوزيعها على عينة الدارسة باستخدام طريقة العينة العشو ائية أهم النتائج التي توصلت إليها الدارسة: نوجد علاقة إيجابية ذات دلالة إحصائية بين أبعاد جودة الحياة الوظيفية ومستوى الالتزام التنظيمي في وازرتي العمل والتنمية الاجتماعية، نبين أن المتغيرات المؤثرة في الالتزام التنظيمي هي (ظروف العمل المادية، التوازن بين الحياة والعمل، الأجور و المكافآت، الأمان و الاستقر ار الوظيفي) وكان هذا التأثثر ذو دلالة إحصائية. ومن أهم توصيات الدر اسة: ضرورة الاهتمام برفع مستوى جودة الحياة الوظيفية في وزارة التنمية الاجتماعية، من خلال انتظام صرف الرواتب وتبني مبدأ العدالة وإتاحة الفرصة أمام الموظفين للمشاركة في اتخاذ القرارات مما يزيد التقة من قدراتهم ومهار اتهم.

9-3-2 دراسة حسن هيام (2018). بعنوان (استخدام استراتيجيات التدريب وجودة الحياة الوظيفية لتحقيق جودة التعليم العالي في الجامعات المصرية)، هدفت الدراسة الى بحث وتحليل العلاقة بين استراتيجيات تنمية وتظوير الموارد البثرية ومنها ( استر اتيجية التدريب وجودة الحياة الوظيفية ) وتأثير ها على مستوى جودة التعليم العالي بالجامعات المصرية، توصلت الدر اسة الى وجود علاقة طردية ذات دلالة إحصائية بين استر اتيجية التدريب و جودة الحياة الوظيفية كما أنشارت النتائج الى وجود تباين و اختلاف الأهمية النسبية لأبعاد استر اتيجية التدريب وجودة الحياة المؤثرة على جودة التعليم العالي، وفي ضوء تللك النتائج تم التوصل الى بعض التوصيات منها ضرورة الاهتمام بنوفير الاستر اتيجيات الأساسية اللازمة لتتمية وتطوير الموارد البشرية في الجامعات 
و ضرورة أن بتم توفير الاهتمام الكافي من قبل الجامعات بالعملية التدرييية و أن تهتم الجامعات بوجود معاير محددة لعملية تقييم الأداء كما ينبغي أن تكون أسس التقييم واضحة لجميع العاملين في الجامعة. 10-3-2 دراسة أبو عودة محمد إسماعيل (2018)، بعنوان (أثر جودة الحياة الوظيفية في تحقيق التمبز المؤسسي "دارسة تطبيقية على منظمات المجتمع المدني)، هدفت الدراسة الى التعرف على أثر جودة الحياة الوظيفية في تحقيق التميز المؤسسي "دارسة تطبيقية على منظمات المجتمع المدني" في قطاع غزة، وتم استخدام استبانة لجمع البيانات على عينه عددها 255، ومن اهم النتائج وجود علاقة ذات علاقة دلاله إحصائية بين كل من (الأجور، الاستقر ار الوظيفي، التقدم الوظيفي) ومن اهم التوصيات التي تم ذكرها العمل على تشكيل نقابة خاصة للعاملين بالمجتمع المدني للمساهمة في معالجة قضاياهم وخاصة الاستقرار الوظيفي وتقديم التسهيلات اللازمة لتطوير قدر اتهم العلمية.

2-3-2 تعليق الباحثّة على الاراسات السابقة. بعد مراجعة الباحثة للاراسات السابقة التي تطرقت الى المو اضيع ذات العلاقة بموضوع الدر اسة و التي أجريت في مناطق مختلفة من العالم، تم تحديد عدد من المؤشرات التي تم ذكر ها في الدر اسات السابقة.

1-2-3-2 وجود اتفاق على أهمية تدريب الموارد البشرية لتحقيق أهداف المنظمة كما يعتبر التدريب من اهم عوامل ترقية العاملين حيث بساعدهم في التغلب على كثير من مشاكل الأداء في عملهم أيضا أن توفير البيئة التدريية المناسبة نساعد على نجاح العملية التدريبية، كما أن للتكنولوجيا دور في رفع كفاءة البرامج التدريبية و أهية دعم ومساندة الإدارة العليا للعملية التدريبية، وأهمية جودة الحياة الوظيفية على أداء العاملين.

2-2-3-2 تتميز الدراسة الحالية عن الدراسات السابقة بأنها حاولت قياس الأثر المباشر للتدريب على جودة الحياة الوظيفية، كما تميزت الدراسة الحالية في نوع القطاع الذي قامت بدراسة أثر التدريب عليه وهو قطاع المصارف تحديدا البنك الأهلي التجاري السعودي، حيث تعتقد الباحثة بان هذه الدراسة من الدر اسات القليلة في حدود علمها على المستوى المحلي في موضوع الدراسة ومتغير اتها، حيث يركز الجانب الأول من الدراسة على بلى به مفهوم التدريب وأهميته ومر احله ويركز الجانب الآخر على جودة الحياة و أبعادها وتحدياتها.

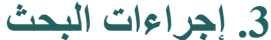

تمهيد. تقوم الباحثة في هذا الفصل بتناول منهج الدراسة الذي تم اتباعه مع تحديد مجتمع وعينة الدر اسة، الأدوات المستخدمة في جمع البيانات وطرق الإحصاء في هذه الدر اسة، و الطرق المتبعة في صدق وثبات الاستبانة، كذلك متغير ات الدر اسة و الإجر اءات المتبعة في المعالجة الإحصائية لتحليل النتائج. 
1-3 نموذج الدراسة. يعبر الثكل رقم (1/3) عن نموذج الدراسة الذي يمثل العلاقة التي تربط بين التدريب وجودة الحياة الوظيفية.
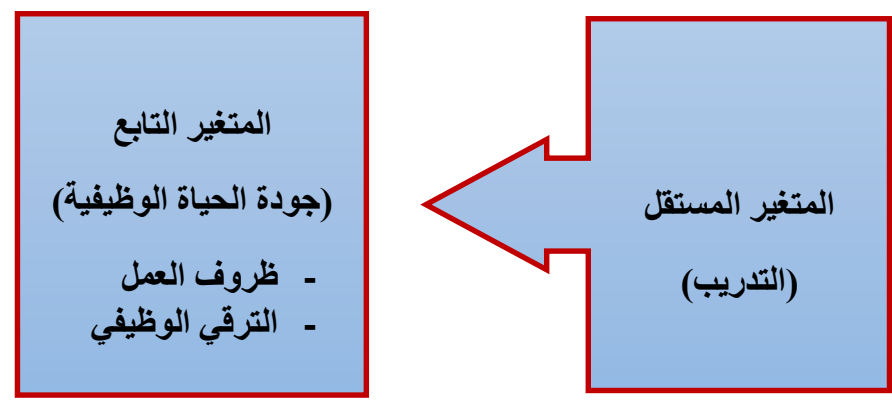

$$
\text { الثكل رقم (1/3) نموذج الدر اسة }
$$

المصدر : نم تطوير نموذج الدر اسة من قبل الباحثة

$$
\text { 2-3 التعريفات الإجرائية }
$$

3-2-3 التدريب. التدريب عملية مستمرة منظمة تهدف الى تزويد المورد البشري بمهار ات ومعلومات وخبرات

$$
\text { و أنماط سلوكية جديدة تؤدي الى تحسين أدائهم وبالتالي أداء المنظمة ككل. }
$$

2-2-3 جودة الحياة الوظيفية. هي استجابة المنظمة لأفضل الأساليب التي تساعد على تحسين بيئة العمل و إنباع

الاحتباجات البثرية لاى العاملين، ويؤدي ذلك الى تحقيق جودة حياة العمل الى نتائج إيجابية للفرد

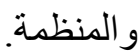

3-3 - 3 أداة البحث

نم الاستعانة باستبانة محكمة عن التدريب من المصدر الأسـسي (العجيلي،عمرو وصفي،2018) و عن المتغير جودة الحياة من المصدر الأساسي (أبو عوده،محمود،2018)، وبتصرف الباحثة.

اعتمدت الباحثة في در استها على المنهج الوصفي التحليلي الذي يعني الطريقة المنظمة لدر اسة الحقائق متعلقة بظاهرة أو موقف أو أفر اد أو أوضاع معينة بهدف اكتشاف حقيقة جديدة أو التأكد من صحة حقائق و أثنار ها و العلاقات المنبثقة

عنها مع تسجيل دلالتها وكثف ارتباطها بمتغير ات أخرى ولفت النظر الى أبعادها المختلفة، لذلك اختارت الباحثة المنهج الوصفي التحليلي لوصفه للظاهرة وصفا دقيقا وتحليلها كما وكيفا باستخدام برنامج

5-3 ثبات الأداة. بعد تطبيق الاسـنبانة على عينة الدر اســة، قامت الباحثة باســتخر اج معامل ثبات الأداة ألفا كرونباخ لمحاور الاستبانة، وكذلك الثبات الكلي للاستبانة، ويبين الجدول (1) معاملات ثبات الاستبانة. 
جدول (1/3) معامل الثبات ألفا كرونباخ لمحاور الاستبانة

\begin{tabular}{|c|c|}
\hline معامل ألفا كرونباخ & 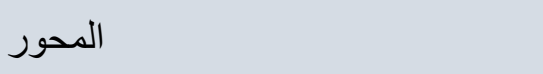 \\
\hline 0,93 & التدريب \\
\hline 0,94 & جودة الحياة الوظيفية (الترفي الوظيفي) \\
\hline 0,93 & جودة الحياة الوظيفية (ظروف العمل) \\
\hline 0,96 & الثبات الكلي للاستبانة \\
\hline
\end{tabular}

يظهر من الجدول (1) بـأن الاســنبانـة تتمتع بمعاملات ثبات ممتازة، حيث بلغ ثبات المحور الأول (0,93) و المحور الثاني (0,94) و المحور الثالث (0,93) وكامل الاستبانة (0,96)، و التي تعتبر معاملات ثبات جيدة تؤهل الأداة لتحقيق

أهداف الدراسة (Taber, 2016)

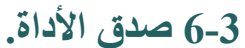

3-5-1 الصدق الداخلي أو صدق الاتسـاق. نم استخدام بيانات العينة في استخر اج معاملات الارتباط للتحقق من

الصدق الداخلي للاستبانة (ارتباط العبار ات بمحاور الاستبانة)، حيث تم استخدام معامل ارتباط بيرسون للحصــول على معاملات الارتباط، ويبين الجدول (2) نتائج معاملات ارتباط العبار ات بمحاور الاسـتبانة،

$$
\text { وبالمتوسط العام لاستجابات الأفر اد في كامل الاستبانة. }
$$

جدول (2/3) معاملات ارتباط العبارات بمحاور الاستبانة وبالاستبانة ككل

\begin{tabular}{|c|c|c|c|c|c|}
\hline \multicolumn{2}{|c|}{ المحور الثالث } & \multicolumn{2}{|c|}{ المحور الثاني } & \multicolumn{2}{|c|}{ المحور الأول } \\
\hline معامل الارتباط & العبارة & معامل الارتباط & العبارة & معامل الارتباط & العبارة \\
\hline$* * 0.919$ & 1 & $* * 0.902$ & 1 & $* * 0.864$ & 1 \\
\hline$* * 0.821$ & 2 & $* * 0.872$ & 2 & $* * 0.867$ & 2 \\
\hline$* * 0.915$ & 3 & $* * 0.879$ & 3 & $* * 0.872$ & 3 \\
\hline$* * 0.937$ & 4 & $* * 0.895$ & 4 & $* * 0.902$ & 4 \\
\hline$* * 0.834$ & 5 & $* * 0.948$ & 5 & $* * 0.867$ & 5 \\
\hline & & & & $* * 0.821$ & 6 \\
\hline$* * 0.913$ & الارتباط الكلي & $* * 0.919$ & الارتباط الكلي & $* * 0.935$ & الارتباط الكلي \\
\hline
\end{tabular}

(0.01) (0.0) دال عند مستوى الدالالة * دال عند مستوى الدلالة (0.05).

بالنظر إلى الجدول (2/3)، يتضـــح وجود ارنباطات قوية دالة عند مســتوى الدلالة (0.01)، ويشــير ذلك إلى وجود ارتباط عالٍ بين العبار ات والمحاور التي تنتمي إليها، كما ترتبط متوسـطات المحاور الثناثة بالمتوســ العام للاسـتبانة بمعاملات ارتباط عالية أيضاً، ويدل ذلك على تمتع الاستبانة بصدق داخلي عالٍٍ يجعلها صالحة لتحقيق أهداف الدراسة. 
المجلة الدولية لنشر البحوث والدراسات

International Journal of Research and Studies Publishing
المجلد الثالث - الإصدار الخامس والعشرون

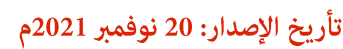

ISSN: 2709-7064

7-3 خصـائص عينة الاراسـة. ب بعد تطبيق الأداة على عينة الدراسـة التي بلغت (170) فرداً، تم اسـتخر اج التكرارات

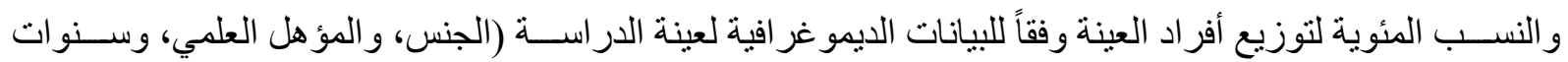

الخبرة)، وييين الجدول (3) توزيع عينة الدراسة وفق البيانات الديموغر افية للار اسة.

جدول (3/3) توزيع العينة وفقاً لمتفيرات الدراسة

\begin{tabular}{|c|c|c|c|}
\hline النسبة المئوية & التكر ار & \multicolumn{2}{|c|}{ متغير ات الدر اسة } \\
\hline$\% 54.1$ & 92 & ذكر & \multirow{2}{*}{ الجنس } \\
\hline$\% 45.9$ & 78 & أنثى & \\
\hline$\% 8.2$ & 14 & 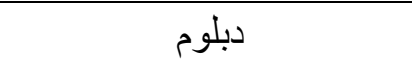 & \multirow{3}{*}{ المؤهل العلمي } \\
\hline$\% 69.4$ & 118 & جامعي & \\
\hline$\% 22.4$ & 38 & در اسات عليا & \\
\hline$\% 22.4$ & 38 & أقل من 5 سنو ات & \multirow{3}{*}{ سنوات الخبرة } \\
\hline$\% 40.0$ & 68 & من 5 إلى أقل من 10 سنو ات & \\
\hline$\% 37.6$ & 64 & من 10 سنو ات فأكثر & \\
\hline
\end{tabular}

يتضح من الجدول (3) بأن أعداد الذكور و الإناث من أفراد العينة متقاربة إلى حد ما، كما يتضح بأن معظم أفر اد العينة

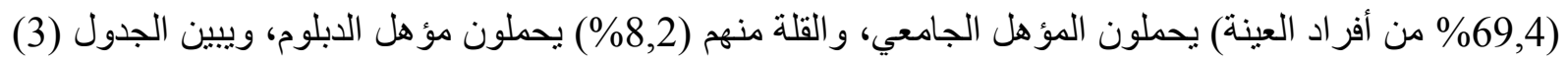

أيضاً بأن معظم أفر اد العينة يملكون خبرة وظيفية بعمل لفترة من (5) سنوات إلى (10) سنوات إلى أعلى من (10) سنو ات. ويبين الثكل (1، 2، 3) رسماً بياناً لتوزيع أفر اد العينة وفق البيانات الديمو غر افية.

شكل (2/3) الرسم البياني لتوزيع أفراد العينة وفق متغير الجنس

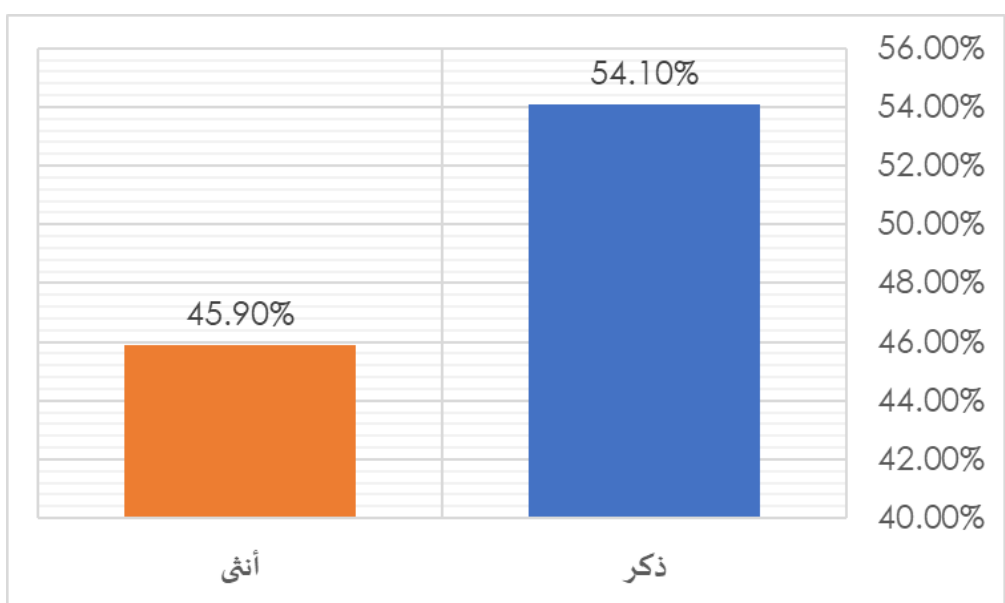

يتضح من خلال الثكل (2) ان أعداد الذكور و الإناث من أفر اد العينة متقاربة الى حد ما. 
المجلة الدولية لنشر البحوث والدراسات

International Journal of Research and Studies Publishing

ISSN: 2709-7064
المجلد الثالث - الإصدار الخامس والعشرون تأريخ الإصدار: 20 نوفمبر 2021م المجد الثار

شكل (3/3) الرسم البياني لتوزيع أفر اد العينة وفق متغير المؤهل

\begin{tabular}{|c|c|c|c|}
\hline & $69.40 \%$ & & \\
\hline & & & $60.00 \%$ \\
\hline & 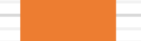 & & $50.00 \%$ \\
\hline & & & $40.00 \%$ \\
\hline $22.40 \%$ & & & $30.00 \%$ \\
\hline & & $820 \%$ & $20.00 \%$ \\
\hline & 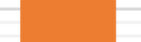 & - & $10.00 \%$ \\
\hline دراسات عليا & جامعى & ديلوم & \\
\hline
\end{tabular}

يتضح من الثكل (3) بأن معظم أفر اد العينة 96.40 من حملة المؤهل الجامعي وتعني أن سياسة البنك تسعى نحو تعيين أصحاب المؤهلات الجامعية في وظائفه.

شكل (4/3) الرسم البياني لتوزيع أفر اد العينة وفق متغير سنوات الخبرة

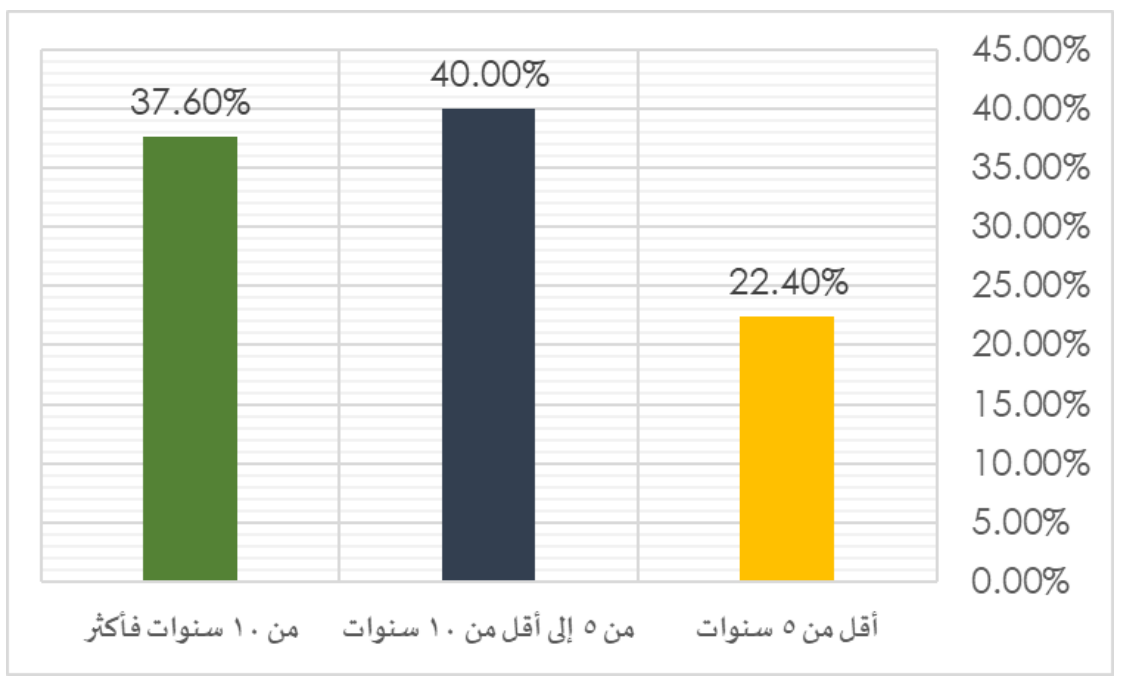

يتضح من الثكل (4) أن معظم أفر اد العينة يملكون خبرة وظيفية جيدة حيث أن معظمه عملو الفترة من (5) سنوات الى (10) سنو ات.

4. تحليل البيانات

تقوم الباحثة في هذا الفصل بتحليل البيانات ومناقشتها وربطها بالإطار النظري وفحص فرضيات الدر اسة.

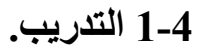


المجلة الدولية لنشر البحوث والدراسات

International Journal of Research and Studies Publishing

ISSN: 2709-7064
المجلد الثالث - الإصدار الخامس والعشرون تأريخ الإصدار: 20 نوفمبر 2021م الإمدار

1-1-4 مستويات التدريب.

جدول (1/4) التكرارات والنسب المئوية والمتوسطات الحسابية لكل عبارة من عبارات محور التدريب

\begin{tabular}{|c|c|c|c|c|c|c|c|c|c|}
\hline الانحر اف & الحسابي & بثو افق & |مو افق & |محايد & غو افير & 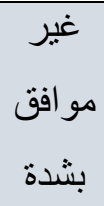 & & العبارة & رقارة \\
\hline \multirow{2}{*}{1.09} & \multirow{2}{*}{3.85} & 53 & 83 & 12 & 16 & 6 & تكر ار & \multirow{2}{*}{ | وفقا للاحتياجات البر امج التدريبية في البنكي } & \multirow{2}{*}{1} \\
\hline & & 31.8 & 38.8 & 15.3 & 10.6 & 3.5 & نسبة & & \\
\hline \multirow{2}{*}{1.04} & \multirow{2}{*}{3.95} & 53 & 83 & 12 & 16 & 6 & تكر ار & \multirow{2}{*}{ |أداء محددة وقابلة للقياس. توضع أهداف البر امج التدريبية } & \multirow{2}{*}{2} \\
\hline & & 31.2 & 48.8 & 7.1 & 9.4 & 3.5 & نسبة & & \\
\hline \multirow{2}{*}{1.12} & \multirow{2}{*}{3.65} & 41 & 66 & 33 & 22 & 8 & تكر ار & \multirow{2}{*}{ وينم تقيبم مخرجات التدريب } & \multirow{2}{*}{3} \\
\hline & & 24.1 & 38.8 & 19.4 & 12.9 & 4.7 & نسبة & & \\
\hline \multirow{2}{*}{1.20} & \multirow{2}{*}{3.21} & 31 & 38 & 49 & 40 & 12 & تكر ار & \multirow{2}{*}{ |لإدارية والتدريب كافة مجالات العمل } & \multirow{2}{*}{4} \\
\hline & & 18.2 & 22.4 & 28.8 & 23.5 & 7.1 & نسبة & & \\
\hline \multirow{2}{*}{1.15} & \multirow{2}{*}{3.68} & 45 & 61 & 40 & 12 & 12 & تكر ار & \multirow{2}{*}{ 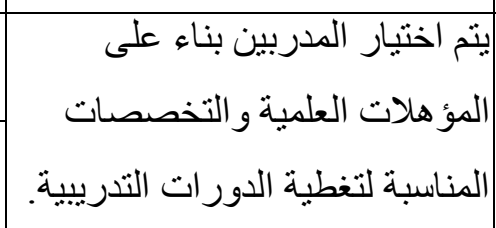 } & \multirow{2}{*}{5} \\
\hline & & 26.5 & 35.9 & 23.5 & 7.1 & 7.1 & نسبة & & \\
\hline \multirow[b]{2}{*}{1.18} & \multirow[b]{2}{*}{3.85} & 58 & 64 & 24 & 12 & 12 & تكر ار & \multirow{2}{*}{ 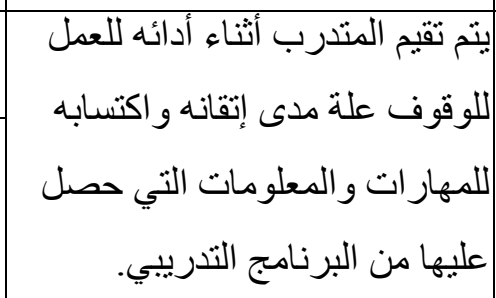 } & \multirow[b]{2}{*}{6} \\
\hline & & 34.1 & 37.6 & 14.1 & 7.1 & 7.1 & نسبة & & \\
\hline
\end{tabular}

يتضـح من الجدول (1/4) بأن العبارة (تشـتمل أهداف البرامج التدرييية التي توضـع في البنك على معايير أداء محددة وقابلة للقياس) حصـلت على أعلى منتوسـط، حيث بلغ منوسـط اسـتجابات العينة على هذه الفقرة (3,95)، وبانحر اف معياري بلغ (1,04). كمـا يبين الجدول (6) من جهة أخرى بأن العبارة (يشـــل التدريب كافة مجالات العمل الإدارية

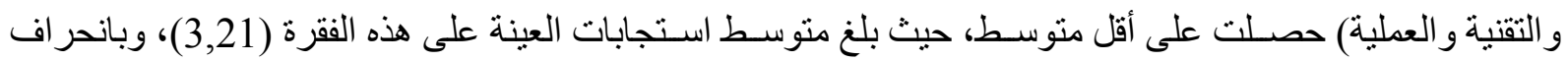

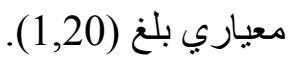


المجلة الدولية لنشر البحوث والدراسات

International Journal of Research and Studies Publishing

ISSN: 2709-7064
المجلد الثالث - الإصدار الخامس والعشرون

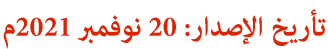

2-1-4 مستوى جودة الحياة الوظيفية (الترقي الوظيفي).

جدول (2/4) التكرارات والنسب المئوية والمتوسطات الحسابية لكل عبارة من عبارات محور جودة الحياة الوظيفية

(الترقي الوظيفي)

\begin{tabular}{|c|c|c|c|c|c|c|c|c|c|}
\hline الانحر اف & الحسب المتي & بثندة & مو افق & محايد & 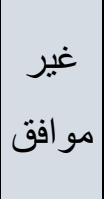 & بثير & & العبارة & 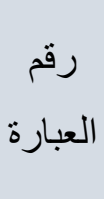 \\
\hline \multirow[t]{2}{*}{1.39} & \multirow[t]{2}{*}{3.15} & 29 & 57 & 28 & 22 & 34 & تكر ار & \multirow[t]{2}{*}{ تطبق الترقيات على أسس } & \multirow[t]{2}{*}{1} \\
\hline & & 17.1 & 33.5 & 16.5 & 12.9 & 20.0 & نسبة & & \\
\hline \multirow{2}{*}{1.41} & \multirow{2}{*}{3.05} & 31 & 42 & 37 & 24 & 36 & تكر ار & \multirow{2}{*}{ الترقيد البنك على مبدأ الجدارة في } & \multirow{2}{*}{2} \\
\hline & & 18.2 & 24.7 & 21.8 & 14.1 & 21.2 & نسبة & & \\
\hline \multirow{2}{*}{1.39} & \multirow{2}{*}{3.26} & 36 & 50 & 40 & 10 & 34 & تكر ار & \multirow{2}{*}{ و يصمح البنأك مسارات وظيفية } & \multirow{2}{*}{ J } \\
\hline & & 21.2 & 29.4 & 23.5 & 5.9 & 20.0 & نسبة & & \\
\hline \multirow{3}{*}{1.40} & \multirow{3}{*}{2.95} & 34 & 26 & 42 & 34 & 34 & تكر ار & \multirow{3}{*}{ 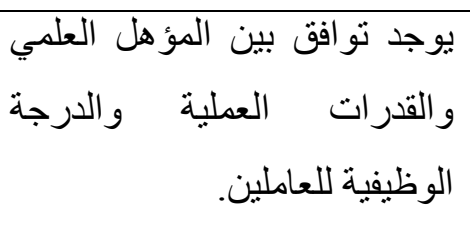 } & \multirow{3}{*}{4} \\
\hline & & & & & & & & & \\
\hline & & 20.0 & 15.3 & 24.7 & 20.0 & 20.0 & نسبة & & \\
\hline \multirow{2}{*}{1.47} & \multirow{2}{*}{3.31} & 48 & 36 & 42 & 8 & 36 & تكر ار & \multirow[t]{2}{*}{ للترقي الوظيفي للعاملين. مستقلية متاحة } & \multirow{2}{*}{5} \\
\hline & & 28.2 & 21.2 & 24.7 & 4.7 & 21.2 & نسبة & & \\
\hline
\end{tabular}

بتضـــح من الجدول (2/4) بأن العبارة (يوجد فرص مســتقبلية متاحة للترقي الوظيفي للعاملين) حصــلت على أعلى متوسط، حيث بلغ متوسط استجابات العينة على هذه الفقرة (3,31)، وبانحر اف معياري بلغ (1,47). كما يبين الجدول (7) من جهة أخرى بأن العبارة (يوجد تو افق بين المؤهل العلمي والقدرات العملية و الدرجة الوظيفية للعاملين) حصلت على أقل منوسط، حيث بلغ متوسط استجابات العينة على هذه الفقرة (2,95)، وبانحر اف معياري بلغ $(1,40)$. 
المجلة الدولية لنشر البحوث والدراسات

International Journal of Research and Studies Publishing

ISSN: 2709-7064
المجلد الثالث - الإصدار الخامس والعشرون تأريخ الإصدار: 20 نوفمبر 2021م الإمدار

3-1-4 مستوى جودة الحياة الوظيفية (ظروف العمل).

جدول (3/4) التكرارات والنسب المئوية والمتوسطات الحسابية لكل عبارة من عبارات محور جودة الحياة الوظيفية

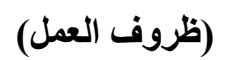

\begin{tabular}{|c|c|c|c|c|c|c|c|c|c|}
\hline الانحر اف & المتوسط & بشدة & مو افق & محايد & مو افق & 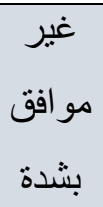 & & العبارة & 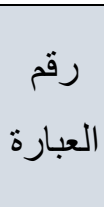 \\
\hline \multirow{2}{*}{1.19} & \multirow{2}{*}{3.78} & 52 & 66 & 28 & 10 & 14 & تكر ار & \multirow{2}{*}{ كيفية العمل في بيئة آنية. } & \multirow{2}{*}{1} \\
\hline & & 30.6 & 38.8 & 16.5 & 5.9 & 8.2 & نسبة & & \\
\hline \multirow{2}{*}{1.20} & \multirow{2}{*}{3.53} & 43 & 50 & 43 & 22 & 12 & تكر ار & \multirow{2}{*}{ الاحتياجات للعاملين في إنجاز } & \multirow{2}{*}{2} \\
\hline & & 25.3 & 29.4 & 25.3 & 12.9 & 7.1 & نسبة & & \\
\hline \multirow{2}{*}{1.22} & \multirow{2}{*}{3.65} & 48 & 60 & 28 & 22 & 12 & تكر ار & \multirow{2}{*}{ بشالارنباح ب بخصوص مكان العمل. } & \multirow{2}{*}{3} \\
\hline & & 28.2 & 35.3 & 16.5 & 12.9 & 7.1 & نسبة & & \\
\hline \multirow{2}{*}{1.28} & \multirow{2}{*}{3.81} & 66 & 52 & 20 & 18 & 14 & تكر ار & \multirow{2}{*}{ و يوفر البنلك ظروف لكافة العاملين. } & \multirow{2}{*}{4} \\
\hline & & 38.8 & 30.6 & 11.8 & 10.6 & 8.2 & نسبة & & \\
\hline \multirow{3}{*}{1.26} & \multirow{3}{*}{3.75} & 62 & 46 & 34 & 14 & 14 & تكر ار & \multirow{3}{*}{ 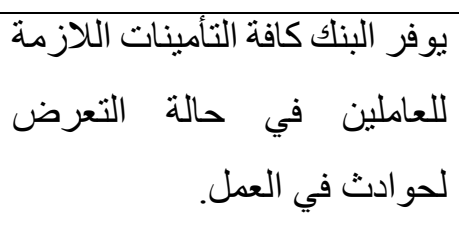 } & \multirow{3}{*}{$J$} \\
\hline & & & & & & & & & \\
\hline & & 36.5 & 27.1 & 20.0 & 8.2 & 8.2 & نسبة & & \\
\hline
\end{tabular}

يتضح من الجدول (3/4) بأن العبارة (يوفر البنك ظروف الآمن والسـلامة لكافة العاملين) حصلت على أعلى منوسط، حيث بلغ منوسط استجابات العينة على هذه الفقرة (3,81)، وبانحر اف معياري بلغ (1,28). كما يبين الجدول (8) من

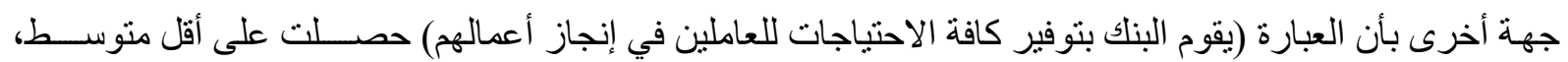

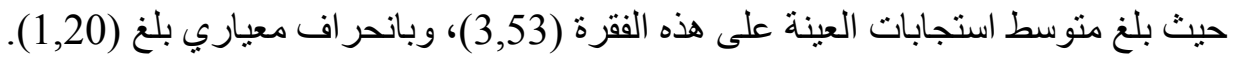
2-4 التحقى من فرضيات الدراسة.

1-2-1 التحقق من الفرضية الأولى. نصت الفرضية الأولى للدر اسة على أنه "توجد علاقة ذات دلاله إحصائية بين مستوى التدريب وتحقيق ظروف العمل الصحية"، 
وللتحقق من الفرضية الأولى تم استخدام معامل ارتباط بيرسون (Pearson Correlation) لإيجاد دلالة الارتباط بين المتغيرين. ويبين الجدول (9) نتائج معامل ارتباط بيرسـون لإيجاد دلالة العلاقة بين مســتوى التدريب وتحقيق ظروف العمل الصحية لدى الموظفين.

جدول (4/4) نتائج معامل ارتباط بيرسون لإيجاد دلالة العلاقة بين مستوى التريب وتحقيق ظروف العمل الصحية لاى الموظفين

\begin{tabular}{|c|c|c|}
\hline عديمة الارتباط & عندينة & \\
\hline 0.000 & 0.784 & 170 \\
\hline
\end{tabular}

يتبين من الجدول (4/4) بوجود علاقة دالة إحصــائياً عند مســتوى الدلالة (0,01) أو أقل منه، بين مســتوى التدريب وتحقيق ظروف العهل الصـــحية في البنك الأهلي التجاري، ويتبين من قيمـة معـامل الارتبـاط (0,784) بـأن العلاقة موجبة (طردية) بين المتغيرين.

2-2-4 التحقق من الفرضية الثانية. نصـت الفرضية الثانية للار اسـة على أنه: "توجد علاقة ذات دلاله إحصـائية بين

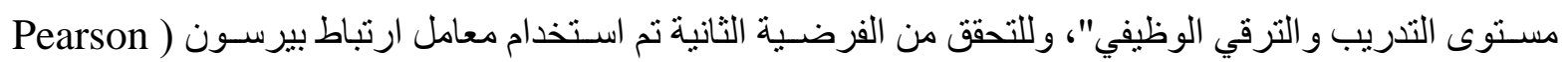
(Correlation العلاقة بين مستوى التدريب و الترقي الوظيفي لاى الموظفين.

جدول (5/4) نتائج معامل ارتباط بيرسون لإيجاد دلالة العلاقة بين مستوى التدريب والترقي الوظيفي لاى الموظفين

\begin{tabular}{|c|c|c|}
\hline عدد العينة & مستوى الدلالة & 170 \\
\hline 0.000 & 0.805 & (لارتباطة \\
\hline
\end{tabular}

يتبين من الجدول (5/4) بوجود علاقة دالة إحصــائياً عند مســتوى الدلالة (0,01) أو أقل منه، بين مســتوى التدريب و الترقي الوظيفي في البنك الأهلي التجاري، ويتبين من قيمـة معامل الارتبـاط (0,805) بأن العلاقة موجبـة (طردية) بين المتغيرين.

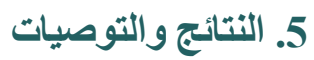

توصلت الباحثة من خلال أدبيات الدر اسة وتحليل بيانات الدراسة الميدانية ونتائج التحليل الإحصائي واختبار فروض البحث الي العديد من النتائج أهمها ما يلي: 
1. تبين من خلال تحليل البيانات الثخصية والديمغر افية للمبحوثين من منسوبي البنك الأهلي التجاري بأن أعداد

$$
\text { الذكور و الإناث من أفر اد العينة متقاربة إلى حد ما. }
$$

2. بتضح بأن معظم أفراد العينة 69,4\% من حملة المؤهل الجامعي وهي أكثر من النصف وهذا يعطي مؤشر

إيجابي ويعني أن سياسة البنك تسعى نحو تعبين أصحاب المؤهلات الجامعية في وظائفه.

3. معظم أفر اد العينة بملكون خبرة وظيفية جيدة حيث أن معظمه عملو الفترة من (5) سنوات إلى (10) سنو ات.

4. ما نسبته (91.4) تتر اوح أعمار هم ما بين ( 36 - 45 سنة) مما يشير إلى أن وزارة التجارة بالمملكة العربية

$$
\text { السعودية تتجه نحو تعين الثباب و الناضجين في الوظائف العليا و الوسطي. }
$$

5. أظهر التحليل الإحصائي والاختبار ات و المقاييس الإحصائية التي استخدمت في هذه الدر اسة إثبات صحة جميع

$$
\text { فروض البحث. }
$$

6. تبين الدر اسة اهتمام البنك الأهلي التجاري بتدريب منوسبيه وتقديم الدورات وورش التدريب في معظم أنشطة

البنك.

7. أظهرت الدر اسة ان عبارة " يقوم البنك بتدريب العاملين على كيفية العمل في بيئة آمنة." حصلت على أعلى متوسط حسابي حيث بلغ متوسط استجابات العينة لهذه الفقرة (3.78)، و هذا مؤشر جيد يجب تعزيزه حتى تقل نسبة الذين لا يلرون و الذين لا يو افقون على أن لهم معرفة جيدة بمفاهيم بالتدريب المطلوب.

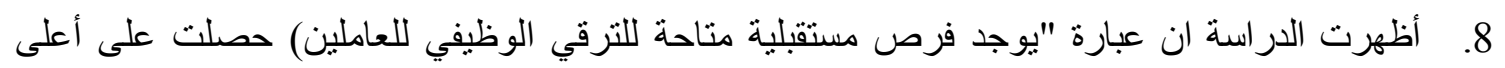
متوسط، حيث بلغ منو سط استجابات العينة على هذه الفقرة (3,31) 9. تبين من الدراسة ان التدريب أثر إيجاباً علي كفاءة وفعالية أداء البنك الأهلي التجاري وذللك من خلال ما تحقق من تطور وتقدم واضح في هذا القطاع. 10. تبين من الدر اسة أن هناك علاقة ارتباطقوية بين معرفة الإدارة العليا و الوسطي بمفاهيم و أساليب التدريب و أهمية تطبيقهاوممارستها. 11. تنين من الدر اسة مساهمة التدريب بصورة كبيرة في جودة الخدمات التي يقدمها البنك الأهلي التجاري. 12. توصلت الدراسة الي أن تطبيق مختلف أنواع التدريب يؤدي إلي كفاءة وفعالية أداء البنك الأهلي التجاري وتنين ان الأداء العام للبنأك يتسم بالكفاءة و الفعالية. 13. أكدت نتائج الدارسة فو ائد ومز ايا التدريب وأثره علي فعالية وجودة الحياة الوظيفية، لذا علي الإدارة العليا في البنك الأهلي التجاري أن تتبني تطبيق وممارسة عملية التدريب في جميع العمليات والأنشطة وبطريقة علمية منظمة، وان تستعين بذوي الخبرة و الاختصاص في هذا الثأن. 
1. لمو اجهة مختلف المشاكل و الصعوبات مع التغيرات الداخلية و الخارجية على البنك الأهلي التجاري وجميع المؤسسات الاقتصادية أن تتبنى فكرة تطبيق التدريب و الاهتمام به.

2. على البنلك الأهلي التجاري مو اصلة القيام بإجر اء التغير ات و التعديلات على خططها واستر اتيجياتها و البحث عن سبل أكثر فعالية وو اقعية للمحافظة على جودة الحياة الوظيفية.

3. ضرورة توفير نوع من التو افق بين أنواع التدريب وجودة الحياة الوظيفية لترقية أدائهم والمهام الموكلة إليهم ضمن

$$
\text { تخصصاتهم لتحقيق أكبر قدر الجودة. }
$$

4. ضرورة الاهتمام بالبحث العلمي وتتجيعه ور عايته، و إنشاء وحدات متخصصة داخل البنك الأهلي التجاري ضمن إدارة التخطيطو المشرو عات تعني بهذا الثأن وضرورة التعاون مع الباحثين وتقديم العون لهم و هذا سينعكس إيجابا علي تطور وتقدم هذا الصرح المالي المعطاء.

5. هذه الرسالة مساهمة أكاديمية لفائدة الطلاب و الباحثين في مجال التدريب ووتجويد الحياة الوظيفية كمرجع أو مصدر في هذا التخصص خاصة ان هذا المجال يتسم بقلة المصادر و المر اجع العربية. وكذلك تعد هذه الرسالة مساهمة تطبيقية كدليل يفيد ويزود الممارسين لأعمال التدريب بأدبيات التدريب إضافة الي النتائج و التوصيات التي توصلت لها هذه الدر اسة و إذا تم العمل بها سنساهم في تحسين أنواع التنريب وتجويد الحياة الوظيفية في معظم المنظمات و الدو ائر.

6. على البنك الأهلي توفير أحدث أنو اع وطرق التدريب الجيدة وتكثيف العمل بها ورصد الخبرات لتحقيق أهدافه ونجاحه. 7. نشر الوعي التدريبي بين الموظفين وذلك بجعل سياسة التدريب و اضحة، و إشر الك الموظف كمحور أساسي في مر احل الإعداد للعملية التدريبية. 8. يجب العمل على إثارة الرغبة في نفس المتدرب ووضع نظام حو افز مبني على نتائج التدريب لتشجيعه على الالتزام ورفع روحه المعنوية المراجع

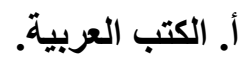
1. هلال، محمد (2001 م). التدريب الأسس و المبادئ، الطبعة الأولى، دار الكتاب، مصر الجديدة. 2. الهميتي، خالد (2003م). إدارة الموارد البثرية، ط1، ص 89، دار و ائل للنشر و التوزيع، عمان. 3. بن عنتر ، عبد الرحمن (د.ت). إدارة الموارد البشرية، ص 88، دار اليازوري العلمية للنشر والتوزيع، عمان

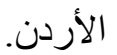

4. التهامي، حسين (2013م). التفكير الابتكاري في السلوك التدريبي في العملية الإدارية (الأسس و المفاهيم و الأبعاد

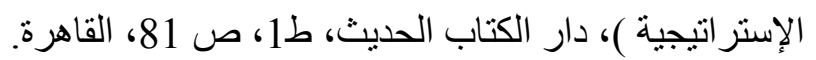


5. أبو بكر ، مصطفى (2004م). إدارة الموارد البشرية، مدخل لتحقيق الميزات التنافسية، الإسكندرية: الدار الجامعية.

$$
\text { 6. الحلبي، حسن (1983م). التدريب الموظف، بيروت منشور ات عويدات ص 14-25. }
$$

7. عساف، عبد المعطي (2000). التدريب وتنمية الموارد البشرية (الأسس والعمليات)،دار زهر ان، عمان-الأردن. 8. ياغي، محمد (2003م). التدريب بين النظرية والتطبيق، ط2، مركز احمد ياسين، عمان-الأردن.

9. عباس، سهيلة (2006م). إدارة الموارد البشرية: مدخل استر اتيجي، دار وائل للنشر، الطبعة الثانية. 10. ماهر، احمد (2005م). إدارة الموارد البشرية، الدار الجامعية للطباعة و النشر والتوزيع، الإسكندرية، مصر. 11. ابن عيشي، عمار (2012م). اتجاهات التدريب المعاصرة وتقييم أداء الأفراد، الطبعة الثانية، دار أسامة للنشر

$$
\text { و التوزيع، عمان. }
$$

12. حمزة، محمد (2014م). دليل (إعداد مواد التدريب ) قسم التنسيق و العمليات MSB وكالة الطو ارئ المدنية السويدية.

13. السيد، أمل (2007م). إدارة الموارد البشرية، مطابع الدار الهندسية، القاهرة، مصر. 14. عبد الرحمن، أسامه (2017م). معوقات التدريب، دار زهور المعرفة و البركة، طبعة أولى.

$$
\text { 15. حنا، نصر الله (2002م). "إدارة الموارد البشرية"، دار زهران، عمان. }
$$

16. جاد الرب، محمد (2008م). جودة الحياة الوظيفية في منظمات الأعمال العصرية، القاهرة، دار النهضة العربية. 17. السالم، مؤيد سعيد (2009م). إدارة الموارد البشرية المعاصرة، مدخل إستر اتيجي تكاملي، ص353، دار إثراء

$$
\text { النشر. عمان، الأردن. }
$$

18. أبو الثيخة، نادر (2000م). إدارة الموارد البشرية، ص 138، ط1، دار صفاء، الأردن. 19. الهيتي، خالد (2010م). إدارة الموارد البشرية: مدخل استر اتيجي ط3، دار و ائل للنشر، عمان، الأردن. 20. المغربي، عبد الحميد (2009م). الاتجاهات الحديثة في در اسات ممارسات إدارة الموارد البشرية، المكتبة العصرية للنشر والتوزيع، المنصورة، جمهورية مصر العربية.

\section{ب. بالرسائل العلمية.}

1. شذى عبيدات، شذى (2013م). و اقع استر اتيجية وظائف الموارد البشرية في قطاع المصارف الأردنية، جامعة

$$
\text { اليرموك، الأردن. }
$$

2. عواد، نادر (2018م). تطبيق نموذج ADDIE على بر امج التدريب في وزارة التربية والتعليم العالي في

فلسطين، جامعة الخليل، فلسطين. 
3. الجربوع، عبد المجيد (2010م). "دور تحديد الاحتياجات التدريبية في جودة بر امج تنمية العاملين"، رسالة

مقدمة للحصول على درجة الماجستير، جامعة نايف العربية للعلوم الأمنية.

4. البربري، مروان (2016م). دور جودة الحياة الوظيفية في الحد من ظاهرة الاحتراق الوظيفي لدى العاملين في

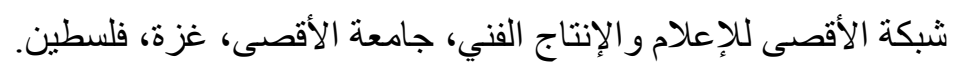

5. الحسني، وسام (2016م). أثز جودة الحياة الوظيفية في تعزيز الالتز ام التنظيمي لاى الطالبين الاجتماعيين في

وزارة الثؤون الاجتماعية بقطاع غزة، رسالة ماجستير غير منشورة كلية الاقتصاد و العلوم الإدارية، جامعة

الأز هر، غزة، فلسطين.

6. محمد، عارف (2011م). "جودة الحياة الوظيفية ودور ها في تطبيق معايير إدارة الجودة الثاملة، جامعة قناة

السويس،جمهورية مصر العربية.

7. البلبيسي، يوسف و زياد، أسامة (2012م). جودة الحياة الوظيفية وأثر ها على الأداء الوظيفي للعاملين في

المنظمات غير الحكومية في قطاع غزة،جامعة غزة، فلسطين.

\section{ج. المراجع الأجنبية.}

1. Edwin B, FILPPO (1976). Principles of personnel management 4th, New York, usamarwahillcompagon, P3

2. Monday, R. Wayne, Robert M, Noe, \& Premeaut, Shane R (2005), "Human Resource Management", Ninth Edition, Prentice Hall, USA

3. Arif, S., \& Ilyas, M. (2013). Quality of work-life model for teachers of private universities in Pakistan. Quality Assurance in Education, 21(3), 282-298.

4. Kaila, H. L. (2006)> Industrial and organizational psychology, India: Kalpaz Publications, Vol.2, pp,430-431

5. Frederick, R. (2002). A companion to business ethics, pp, 272-273

6. Lau R.S, \& May B.E (1998). A win-win paradigm for quality of work life and business performance, Human Resource Development Quarterly, p, 213.

7. Surya Kumar.Shani (2013). A Study on Quality of Work Life Among the Employees at Metro Engineering Private Limited. International Journal of Management, Vol. 4, Issue 1, p.2

8. Havlovic,S.J. (1991).Quality of work life and Human Resource Outcomes. Industrial Relations, 30(3), 469-479. 
9. Taber, Keith S. (2016). The Use of Cronbach's Alpha When Developing and Reporting Research Instruments in Science Education. Research in Science Education, 48(6), 1273-1296.

\section{د. مراجع الاراسات السابقة.}

1. صالح، جهاد (1999)، تقييم فاعلية البرامج التدريية في مراكز التدريب الخاصة من وجهة نظر المتدربين: (در اسة تطبيقية على المصارف التجارية الأردنية)، رسالة ماجستير ، جامعة آل البيت، كلية الاقتصاد و الإدارة. 2. آل بشر ، سعيد صالح، (2004)، تقييم بر امج التدريب في شركة سابك و أثر ها على أداء العاملين،رسالة ماجستير،

$$
\text { جامعة آل البيت، الأردن. }
$$

3. العطوى، صالح (2007) أثر أساليب التدريب على فاعلية البرامج التدريبية في المؤسسة العامة للتعليم الفني و التدريب المهني في المملكة العربية السعودية، دراسة ميدانية، رسالة ماجستير، جامعة مؤته، الكرك: الأردن.

$$
\text { (رسالة من دار المنظومة). }
$$

4. الزهر اني، عبد الله (2012) إستر اتيجية التدريب و أثر ها على الجدار ات السلوكية للعاملين في المصارف التجارية

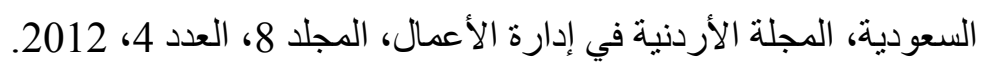

5. Shakeel, S., \& Lodhi, S. (2015). Impact of Training and Development on Employee

Performance: A Case of Banking Sector of Pakistan. The International Journal of Business \& Management, 3(11), 76.

6. الغول، فريد محمد موسي، (2015) جودة الحياة الوظيفية على أداء العاملين في المصارف الإسلامية الأردنية، رسالة دكتور اة، جامعة العلوم الإسلامية العالمية، الأردن.

7. محمد، إيهاب عبد اله، (2016) أثر جودة الحياة الوظيفية على الأداء التنظيمي: (دراسة تطبيقية على قطاع البنوك) المصدر: المجلة العلمية للاقتصاد و التجارة، الناشر : جامعة عين شمس ـ كلية التجارة، ع، 1. 8. البياري، سمر جودة، (2018) الحياة الوظيفية وأثرها على الالتزام التنظيمي لموظفي وزارتي العمل والتنمية الاجتماعية في قطاع غزة، كلية الاقتصاد والإدارة، الجامعة الإسلامية بغزة. 9. حسن، هيام لطفي صالح (2018)، استخدام استراتيجيات التدريب وجودة الحياة الوظيفية لتحقيق جودة التعليم العالي في الجامعات المصرية:در اسة ميدانية، المجلة العلمية للار اسات التجارية و البيئية،جامعة قناة السويس، مج9، $.1 \cdot \varepsilon$ 10. أبو عودة، محمد إسماعيل (2018) أثر جودة الحياة الوظيفية في تحقيق التميز المؤسسي "دارسة تطبيقية على منظمات المجتمع المدني" في قطاع غزة، الجامعة الإسلامية بغزة. 


$$
\text { 1. 1. المراجع الإكترونية. }
$$

https://mawdoo3.com/\%D8\%AA\%D8\%B9\%D8\%B1\%D9\%8A\%D9\%81_\%D8\%A7\%D9 بتاريخ (2020-3-2)

2. https://blog.hotmart.com/ar/\%D8\%AA\%D8\%AF\%D8\%B1\%D9\%8A\%D8\%A8\%D9\%88\%D8\%AA\%D8\%B7\%D9\%88\%D9\%8A\%D8\%B1-

\%D8\%A7\%D9\%84\%D8\%B9\%D8\%A7\%D9\%85\%D9\%84\%D9\%8A\%D9\%86\%D9\%81\%D9\%8A-

\%D8\%A7\%D9\%84\%D8\%B4\%D8\%B1\%D9\%83\%D8\%A7\%D8\%AA/

3. أبو موسى، أسماء (2020، أبريل 14)، التلعيب في التعليم Gamification in Education. تم استرجاعها من. https://www.new-

educ.com/\%d8\%a7\%d9\%84\%d8\%aa\%d9\%84\%d8\%b9\%d9\%8a\%d8\%a8-

\%d9\%81\%d9\%8a-\%d8\%a7\%d9\%84\%d8\%aa\%d8\%b9\%d9\%84\%d9\%8a\%d9\%85 بناريخ (20-04-2020)

$$
\text { 4. بدير، يوسف (2017، نوفمبر، 11)، إعداد خطة التدريب. تم استرجاعها من: }
$$

بتاريخ (01-03-2020). بـ بـt//www.youtube.com/watch?v=D3gQcoi-Zd0

$$
\text { 5. الزهر اني، أحمد، (2019، سبتمبر، 23) تقييم البرنامج التدريبي وقياس أثره على المنظمة. نم استرجاعها من: }
$$
بتاريخ (29)-03-2020).//www.maaal.com/archives/20190929/128762

$$
\text { 6. مادة علمية عن عملية التدريب، تم استرجاعها من. }
$$

https://www.shrm.org/

https://www.cipd.co.uk/ بتاريخ (29-02-2020)

7. البنك الأهلي التجاري السعودي، نم استرجاعها من: https:/Www.alahli.com بتاريخ (2020-03-06).

$$
\text { و. الدوريات والملتقيات. }
$$

1. الفارس، إبر اهيم (2007م). "أهمية التدريب المستمر داخل المنشأة"، ورقة عمل مقدمة في الملتقى العربي

$$
\text { السادس للاستشار ات و التدريب، الرباط، المملكة المغربية. }
$$


2. عبد الرحيم، شيبي و جازية، بن بوزيان (2006). "تقييم كفاءة أداء النظام المصرفي"، الملتقى الوطني حول المنظومة البنكية في ظل التحو لات القانونية والاقتصادية. 3. لطفي، علي (2007م). "التدريب من أجل تنمية الموارد البشرية"، ورقة عمل مقدمة في الملتقى العربي الخامس للاستشار ات و التدريب، خلال الفترة 4-2 يوليو، الأردن. 4. رجاء، رامي (2010م). " ثر التدريب على أداء العاملين في المؤسسة العامة"، مجلة علوم إنسانية، العدد 46،

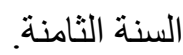
5. صديق، محي الدين (2003). مجلة السودان للإدارة والتنمية، أكاديمية السودان للعلوم الإدارية، المجلد الحادي

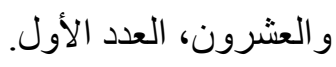

6. ماضي، خليل (2016م). دور متطلبات المنظمة الأخلاقية وجودة الحياة الوظيفية في الحد من ظاهرة الفساد الإداري، در اسة تطبيقية على المنظمات غير الحكومية في قطاع غزة، مجلة ائتلاف من أجل النز اهة والمسائلة. 7.

استطلاعية في الثركة العاملة للصناعات الكهربائية، مجلة الإدارة والاقتصاد، 35 (91)، (187-197. 8. العنزي، سعد الفضل (2007).سما فلسفة نو عبة حياة العمل في منظمات الألفية الثالثة مجلة العلوم الاقتصادية والإدارية. 13 (45)، 68-85، جامعة بغداد، بغداد، العراق. 9. عبطاني، مراد سليم، و أبو سلمى، عبد الله جميل (2014).أثر ممارسة أخلاقيات إدارات الموارد البشرية على بلى تحقيق رضا العاملين: در اسة ميدانية في شركات الاتصالات الخلوية في الأردن،مجلة در اسات العلوم الإدارية. 41 - 2(2)، 388-401 الجامعة الأردنية، عمان، الأردن.

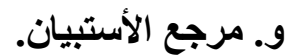

1. العجيلي، عمرو (2018م). رسالة ماجستير "أثر التدريب على أداء العاملين في البنوك التجارية الأردنية "،

جامعة ال البيت، الأردن.

2. أبو عوده، محمود (2018م). رسالة ماجستير "أثر جودة الحياة الوظيفية في تحقيق التميز المؤسسي "؛ الجامعة الإسلامية في غزة، فلسطين.

Doi: doi.org/10.52133/ijrsp.v3.25.3 